\title{
Austerity and gender inequalities in Europe in times of crisis
}

\author{
Cristiano Perugini, Jelena Žarković Rakić and Marko Vladisavljević`
}

\begin{abstract}
The post-2008 recession and the countercyclical responses by European governments that followed triggered an extensive wave of fiscal adjustments. Although underpinned by widespread consensus, the implementation of such measures has also been severely criticised. While their effect on output and employment has been extensively investigated, their impact on wage inequality has received less attention. In this paper, we focus on the consequences of fiscal consolidation measures for gender inequality. After describing the literature-based conceptual framework of our analysis, we provide empirical evidence of the effect of fiscal consolidation on: (i) the adjusted gender wage gap, and (ii) the patterns of gender horizontal segregation. The analysis covers EU-28 countries in the years 2010-13. Results show that austerity measures (both tax-based and expenditure-based) impacted significantly on various aspects of gender wage inequality, putting at risk the relatively little progress achieved in Europe so far.
\end{abstract}

Key words: Austerity, Gender wage inequality, Gender segregation, EU-28 FEL classifications: E62, J16, J31

\section{Introduction}

As a response to the macroeconomic consequences of the post-2008 recession, in particular high public sector deficits and sovereign debt problems, many European Union countries implemented fiscal consolidation programmes, often referred to as austerity measures. The largest were introduced in the 2010-12 period in Hungary, Latvia, Greece, Ireland, Spain and Portugal (Leschke et al., 2015). Although such packages differed in size and structure, most of them included cuts in public sector wages and employment or in public services; some countries embraced policies on the revenue side, such as value-added tax hikes. The effectiveness of fiscal consolidation policies on growth has been extensively questioned, as has their effect on the labour market, inequality and social stability.

The austerity debate goes back to the origins of economic thought and is related to the desirable extent of state intervention into the economy. Konzelmann (2014)

Manuscript received 23 December 2016; final version received 5 June 2018.

Address for correspondence: Cristiano Perugini, Department of Economics, University of Perugia (I), Via A. Pascoli, 20-06123 Perugia, Italy; email: cristiano.perugini@unipg.it

* University of Perugia (I) and Foundation for the Advancement of Economics (FREN), Belgrade (CP); University of Belgrade and FREN, Belgrade (JŽR); and Institute of Economic Sciences Belgrade and FREN, Belgrade (MV).

(C) The Author(s) 2018. Published by Oxford University Press on behalf of the Cambridge Political Economy Society. All rights reserved. 
provides a thorough and exhaustive overview of the austerity debate in the history of economic thought, starting from the different, historically based positions of classical economists such as Malthus, Ricardo and Marx, through to the neoclassical school, the Keynesian era and the growing dominance of neoliberal ideology from the 1970s. Under neoliberalism, policy intervention aimed at achieving full employment has been progressively marginalised, while austerity has increasingly been regarded as a crucial mean of facilitating macroeconomic equilibrium via price stability. Despite the questionable results obtained by neoliberal policies in favouring growth, support for austerity packages gained strength and became, after emergency monetary measures, the most common response to the 2008 recession. Some influential studies provided justification for the widespread adoption of austerity; illustrative examples include evidence that excessive debt is detrimental to growth (Reinhart and Rogoff, 2009) and that fiscal consolidation has an expansionary effect by increasing private sector confidence in a Ricardian equivalence logic (Alesina and Ardagna, 2010). These findings were severely criticised in the following years (e.g. Kinsella, 2012; Herndon et al., 2014; Considine and Duffy, 2016), with a number of studies showing that austerity aggravated the effects of the recession and hit asymmetrically the weakest social and economic groups (Crotty, 2012; Donald et al., 2014). In this context, the impact of fiscal consolidation on gender inequality represents a particularly interesting analytical perspective, and is the focus of this paper.

The crisis is reported to have disproportionally hit male employment, as it most directly affected the male-dominated private sectors (Perivier, 2018). However, what was first seen as 'he-cession' soon after moved to 'sh(e)austerity' (Karamessini and Rubery, 2014). Post-crisis austerity measures such as cuts in public sector wages and employment allegedly impacted women more than men, as women constitute the majority of the workforce in such sectors. Similarly, cuts in tax credits, social benefits and care services could have impacted the quantity and the quality of the labour supplied by women and reshaped gender roles within the household.

In examining the effect of austerity measures on gender inequality, most of the literature to date has dealt with the impact on employment, in particular related to policy interventions in the public sector. On the wage side, attention has been limited to the impact of fiscal consolidation (wage cuts or freezes for public employees) on the raw gender pay gap, that is, on the simple difference in average hourly wages between men and women. However, austerity measures on public sector wages (e.g. a wage cut), while affecting the raw gender gap in the total economy due to a composition effect, impact both men and women symmetrically within the sector. As a result, the gender wage gap 'adjusted' for job and worker characteristics (i.e. which is often ascribed to pure gender discrimination) is expected to remain unaffected. The distinctive feature of our paper is that we are interested in investigating whether austerity increased the scope of gender discrimination practices, that is, increased the gender wage gap once differences in men and women's labour market characteristics have been controlled for. Our working hypothesis is that fiscal consolidation plans, via budget cuts for care policies and social services, disproportionately impact women's ability to supply the requested level of effort, continuity and flexibility on the job. This could exacerbate gender pay inequality by decreasing women's capacity to attain better-paid work positions and by driving downward employers' expectations of women's productivity. 
Our analysis covers EU-28 countries in the years 2010-13 and uses data from the European Union Survey on Income and Living Conditions (EU-SILC). The structure of the article is as follows. After this introduction, Section 2 provides an overview of the evidence available so far in the literature and a discussion of the possible gendered impacts of austerity policies. Section 3 illustrates the micro-level datasets and the variables used, and provides some descriptive evidence on the levels and components of the gender wage gap in Europe. Section 4 describes the data and the indicators used as metrics of fiscal consolidation and provides some preliminary evidence on their possible links with gender inequality. In Sections 5 and 6, we present our econometric models and results. Specifically, Section 5 deals with the estimates of the impact of austerity on the adjusted gender wage gap; Section 6 with the effects of austerity on gender segregation. Section 7 discusses the results and concludes.

\section{Austerity and gender inequalities}

The position of men and women in the labour market, reflected in the level of sectorial and occupational segregation, is critical to understanding the consequences of the great recession. As the crisis hit sectors where the workforce was predominantly male, such as construction, manufacturing and certain branches of finance, the effect of the economic downturn was that labour market conditions deteriorated more for men than for women (Rubery, 2015). The consequent fall in gender disparity observed in Europe after 2008 in terms of employment, unemployment, activity and poverty rates was not a sign of improving gender equality, but rather of the fact that men had moved closer to the most vulnerable positions of women (Bettio and Verashchagina, 2014; Ferreira, 2014; Gonzales Gago and Segales Kirzner, 2014; Addabbo et al., 2015; Perugini, 2017).

Austerity policies that target the public sector, where women are normally overrepresented, are similarly supposed to produce gendered effects (Glasmeier and Lee-Chuvala, 2011). However, the literature that tries to determine how widespread 'she-austerity' was in terms of job losses is still very limited. Using a panel of eight EU countries with different welfare and gender regimes for the period 2008-14, Perivier (2018) shows that the change from 'he-cession to sh(e)austerity' in Europe was limited to Greece and Spain and, to a lesser extent, to the UK and Denmark.

Evidence regarding the impact of austerity measures on gender pay inequality, the focus of this paper, is likewise scarce. Fulton (2011) shows that in Latvia, women's pay in the public sector has fallen disproportionately as a result of austerity measures, causing the raw gender pay gap in the whole economy to rise from $15.2 \%$ in 2008 to $16.9 \%$ in 2011 . In Romania, the raw gender pay gap widened from $7.8 \%$ in 2008 to $12.6 \%$ in 2010 . However, the peak austerity year in Romania was 2010 , when public sector employment was dramatically cut and public sector wages were reduced by $25 \%$ (Stoiciu, 2012).

Besides these direct effects of austerity on the raw gender gap, fiscal consolidation policies could have a number of indirect effects. Budget cuts to alternatives to women's unpaid labour, such as childcare and social and eldercare services, could cause lower female labour participation and also decrease the effort, flexibility and continuity that women are able to put into their job. In Spain, plans to invest in pre-primary school infrastructure were cancelled and significant cuts in long-term care introduced 
(Gonzales Gago and Segales Kirzner, 2014); in Italy, austerity has paused the expansion of childcare services (Verashchagina and Capparucci, 2014), leading to further constraints on mothers' labour supply (Addabbo et al., 2015). In Greece, reduced state budget allocations to municipalities caused a huge decrease in social care staff and the closure of childcare facilities (Karamessini, 2014). In other countries, such as Portugal, means testing was introduced for benefits to which women had previously independent access (Ferreira, 2014). Ireland reduced the amount of child benefits paid directly to mothers (Barry and Conroy, 2014), while Spain abolished them completely (Gonzales Gago and Segales Kirzner, 2014). Ireland also reduced allowances claimed mainly by women looking after elderly or disabled relatives and the contraction in social services resulted in poorer special needs assistance and fewer public nursing home places (Barry and Conroy, 2014). In the UK, a range of measures reduced support for children, pregnancy and childcare. Child benefits and working tax credits were frozen, baby- and pregnancy-related grants were reduced and pressure was exerted on single mothers (as benefit recipients) to increase their efforts to find work (Adam and Brown, 2013; Rubery and Raferty, 2014).

Austerity measures developed in response to the crisis have, therefore, generally led to a retrenchment of the welfare state in childcare and long-term care services, which puts pressure on families to provide informal welfare support, usually in the form of female unpaid labour. This could affect the flexibility of female labour supply, reducing women's chances of being employed in better-paid sectors and challenging achieved levels of integration in the labour market. The longer-run effects of women's more limited contribution to household income could materialise as deterioration in the achieved levels of overall gender equality and endangerment of women's emancipation and autonomy (Ferreira, 2014). In other words, income loss stemming from a decline in employment, benefits and pensions during austerity episodes, coupled with reduced support for work/family reconciliation policies, is expected to reduce female bargaining power within the household and to reinforce the patriarchal family structures (Perivier, 2018).

Evidence supports this hypothesis for example in Germany, where measures focusing on short-term work schemes were implemented as a response to the crisis, in continuity with the structural reforms embedded in the Hartz programme which clearly favoured a conservative, male-centred family model. The Hartz reforms significantly eroded entitlements to benefits in particular for women, first of all by increasingly conditioning unemployment benefits to household resources (rather than to an individual reference wage) and by giving more room to family solidarity. At the same time, reforms imposed wage moderation especially in (female-dominated) services and public sectors (Lehndorff, 2015). When the crisis hit, workers, already on a defensive mode due the Hartz programme, were prepared to make wage concessions given that they anticipated poorer social protection in the case of any lengthy period of unemployment. Short-time working schemes and allowances represented a partial replacement of wages for hours not worked, funded through unemployment insurance. They mainly developed in the industrial sector and essentially concerned men (Knuth, 2014). The reference to the male (main) breadwinner has thereby been reinforced in the income maintenance system (Eydoux, 2014). In Spain, on the other hand, the growth since 2008 of the number of households with only the mother employed seems to challenge the male breadwinner model (Escobedoa and Wall, 2015). This 
could be explained by the very strong 'added worker' effect for women in Spain that Galvez-Munoz et al. (2014) find in their estimation of the labour supply of couple households in Italy and Spain. In Italy, however, despite increased female labour force participation since 2011 in response to the reduction in household income, unfavourable work opportunities (especially in the disadvantaged south) discouraged many women from looking for a job.

All these considerations indicate that fiscal consolidation plans might have significantly weakened the position of women on many levels, by reducing their economic independence, and by imposing heavier family workloads and more labour supply constraints. The resulting reduced effort, availability, flexibility and continuity that women are presumably able to offer in the labour market could have fed a downward adjustment in employers' expectations with regards to women's productivity levels. Together with the consequent expectations of higher variability in women's productivity, and in conditions of incomplete information on the characteristics of individual workers, the scope for 'statistical' labour market discrimination (Phelps, 1972) might have increased. In the absence of perfect information on individuals, employers, relying on average group characteristics, react to the expected higher variability and lower levels of women's productivity by paying lower wages or limiting their access to highpaying jobs (which normally require more flexibility, continuity and effort). From this perspective, austerity episodes might have the potential to become significant turning points in gender relations, employment and welfare states. This could be particularly the case in countries where the move away from traditional patriarchal family structures towards a dual earner model is more recent, and where social norms and attitudes towards women's role in the family and economy are not sufficiently established to resist cyclical policy changes (Rubery, 2014, p. 23).

\section{Gender wage gap in the EU: data, variables and preliminary descriptive evidence}

\subsection{Data and variables}

Our empirical analysis relies on the European Union Survey on Income and Living Conditions (EU-SILC) with reference years from 2010 to 2013. The units of observations are individuals aged between 16 and 65 years who are employed as dependent workers. Individuals not in employment, in education, self-employed or retired are used in the empirical analyses to account and correct for sample selection bias (see below).

The wage variable (PY010G in the dataset) is defined as the gross total (yearly) remuneration, in cash or in kind, payable by an employer to an employee in return for work done in the reference period. It includes wages and salaries paid in cash, holiday payments, 13th-month and overtime payment, profit-sharing, bonuses and productivity premia, allowances paid for transport or for working in remote locations, and the social contributions and income taxes payable by employees. The use of gross wages is common in the literature that considers within-country wage and earnings inequality (Antonczyk et al., 2010) and employs EU-SILC data (Brandolini et al., 2010). In order to account for differences in hours worked, we computed all earning measures on an hourly basis using the information on the number of hours usually worked per week 
in the main job and the number of months spent at work. ${ }^{1}$ The top and bottom $1 \%$ of the hourly wage distributions in each country and year were trimmed in order to avoid distortion by outliers. All monetary values are expressed in 2015 Euro PPPs. ${ }^{2}$

As explanatory variables of wages, besides the gender of the worker, we use a large set of individual information, which includes education, employment status (temporary or permanent), age (and its square), marital status, self-reported health status, place of residence (urban/non-urban region), presence of a second job, full-time employment, type of occupation, and sector and size of the firm in which the individual is employed (see Table A1 for a detailed description of all variables and acronyms used in the analysis). Although extensive, the available information on individual and job characteristics is not exhaustive. Some wage drivers that are likely to differ across genders, such as job tenure and seniority (Munasinghe et al., 2008) ${ }^{3}$ or degree subject (Machin and Puhani, 2003) are not accounted for. Such issues, to the extent that the missing information is not correlated with other available variables, can potentially impact on the estimated gender gap, although some evidence suggests that the distortion is limited (Perugini, 2017). However, our focus here is not estimation of the gender gap but the impact of austerity on gender inequality, and such issues are unlikely to bias the austerity coefficient estimates (see Sections 5 and 6 for details of the empirical model).

\subsection{The gender wage gap and its components}

The descriptive analysis on gender wage gap levels and trends presented here is based on a standard twofold Blinder-Oaxaca decomposition (Blinder, 1973; Oaxaca, 1973). The decomposition splits the difference in the average (log) hourly wages between men and women (the unadjusted gender wage gap) ${ }^{4}$ into explained and unexplained parts (Jann, 2008):

$$
\underbrace{\bar{y}^{M}-\bar{y}^{F}}_{\text {unadjusted pag gap }}=\underbrace{\left(\bar{X}_{k}^{M}-\bar{X}_{k}^{F}\right)^{\prime} \hat{\theta}_{k}^{\star}}_{\text {Explained part of the gap }}+\underbrace{\left(\bar{X}_{k}^{M^{\prime}}\left(\hat{\theta}_{k}^{M}-\hat{\theta}_{k}^{\star}\right)+\bar{X}_{k}^{F^{\prime}}\left(\hat{\theta}_{k}^{\star}-\hat{\theta}_{k}^{F}\right)\right)}_{\text {Un exp lained part of the gap (adjusted pay gap })}, \quad k=1,2, \ldots K
$$

\footnotetext{
${ }^{1}$ We used the EU-SILC variables PL060 (number of hours usually worked per week in main job) and PL073/74 (number of months spent at work as employee). The only assumption needed to compute the total number of hours worked per year is that all employed individuals work four weeks per month.

${ }_{2}$ Despite the efforts made in the EU-SILC to harmonise data, country-level differences in the way wage information is collected and in payment methods persist. However, such issues have a very limited effect on our analysis because we are not comparing absolute wage levels across countries but (relative) wage gaps, and how information is collected and processed within each country does not differ across genders. In addition, in all our empirical analysis, we make use of country fixed effects, which control for all country-level unobserved differences.

${ }^{3}$ Unfortunately, the EU-SILC variable describing work experience (PL200-number of years spent in paid work) presents many missing values (about $27 \%$ of our sample of employees). Missing information is also strongly concentrated in some countries: Denmark (completely missing), Bulgaria, Finland, France, Hungary, Lithuania, the Netherlands, Sweden and Slovenia. The use of the variable would have, therefore, meant excluding those countries from the analysis. The variable 'age' can be considered a good proxy for experience, since their correlation for the available observations is statistically significant and ranges from 0.55 to 0.70 in the four years considered.

${ }^{4} \mathrm{Log}$ transformations are usual in the analysis of wages, as they usually have asymmetric distribution and need to be transformed in order to perform parametric estimations. Additionally, the difference in log wages is approximately equal to the percentage difference between the groups (e.g. Cameron and Trivedi, 2010, p. 86), which enables easier interpretation of results.
} 
where $\bar{y}^{F}$ and $\bar{y}^{M}$ are female and male log wages; $\bar{X}_{k}^{F}$ and $\bar{X}_{k}^{M}$ are the vectors of average female and male workers' and job characteristics; $\theta_{k}^{F}$ and $\theta_{k}^{M}$ are the returns to these characteristics from the two earnings equations; and $\hat{\theta}_{k}^{\star}$ is the vector of reference coefficients (returns), introduced to estimate the explained and the unexplained parts independently from the group viewpoint (Jann, 2008; Avlijaš et al., 2013). We follow Jann (2008) in using the coefficients from the pooled model for both genders (with gender included as a covariate) as the reference coefficients for the decomposition.

The decomposition is estimated on the pooled dataset for the EU-28 countries for all four years (controlling for country and time effects), as well as for each year separately (controlling for country effects) (see Table A2). We perform the same analysis at country level and present the levels of the adjusted wage gap in Table A3. Besides gender, we control for previously listed covariates and sample selection effects, as the selection of employees from the sample of working-age individuals could be nonrandom and therefore produce biases in the estimation of the coefficients from the wage equations. In the field of gender studies, a growing literature has recognised that employed women tend more often to have characteristics normally associated with high wages (Heckman, 1979; De la Rica et al., 2008). As a consequence, low female employment rates may become consistent with a low gender wage gap simply because low-wage women do not feature in the observed wage distribution. To account for the selection effects, we use a correction based on the Heckman two-stage method (Heckman, 1979). First-stage participation equations, in which the dependent variable is coded as 1 if the individual is employed as a dependent worker and 0 otherwise (i.e. self-employed, unemployed, in education, fulfilling domestic tasks, retired, other inactivity status), are estimated separately for each country, year and gender. This first step regressions include a total of $1,304,520$ individuals, of which 677,902 belong to the first group (dependent workers) and the remaining 628,818 to the second. In addition to the already described personal characteristics, we add variables related to household structure that we were able to build based on information available in the EU-SILC. They refer to household size and the number of children (less than 3, 4-6, $7-15$ years old) and elderly (65-74, over 75 years old). Generally speaking, results are consistent with ex-ante expectations: the probability of being employed as a dependent worker increases with age (non-linearly), for married individuals, in urban areas, and with higher education levels. Poor health conditions, larger families and the presence of children or elderlies play the opposite role. Full tables of results for specific genders, countries and years are available upon request. Based on the estimates from the probit equations, we compute a fitted values of an index function and use ratio of the probability density function to the cumulative distribution function of the index function to compute the inverse Mills ratio (IMR) (Wooldridge, 2002). The IMR and its square are then added to the list of covariates in the Blinder-Oaxaca decomposition (equation 1 ), as well as later in estimating the effects of austerity on gender equality.

The difference in log hourly wages between the genders, which equals the unadjusted gender wage gap, is estimated at $13.6 \%$ and was relatively stable between 2010 and 2013 (Table A2); the same holds for the majority of countries. ${ }^{5}$ The negative coefficient

${ }^{5}$ Detailed results of the Blinder-Oaxaca decomposition country by country are not reported here but are available upon request. 

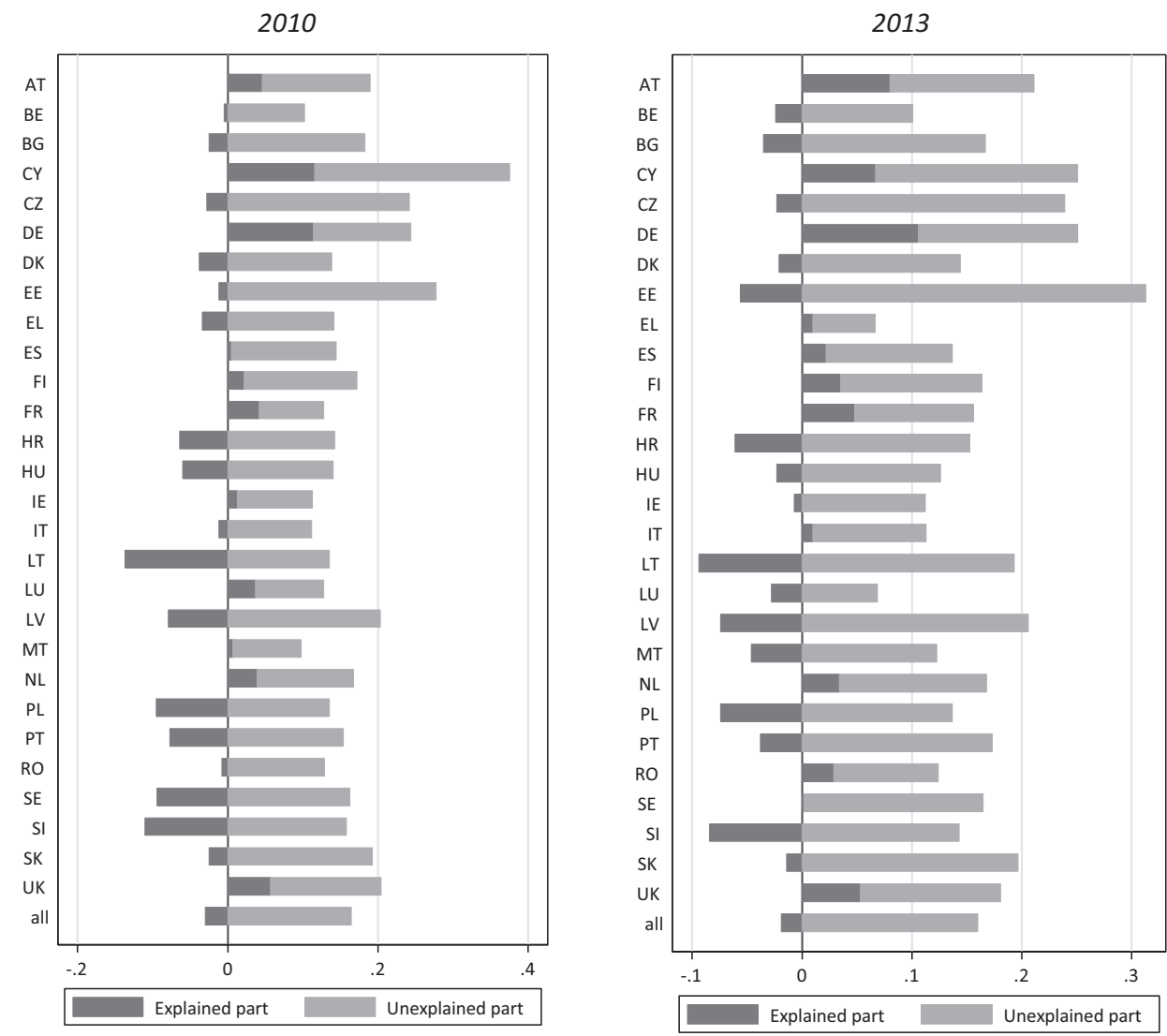

Note: Our elaborations on EU -SILC data; for the country acronyms see Table A 3 in the Appendix

Fig. 1. Explained and unexplained gender wage gap in EU-28 countries (2010 and 2013).

for the explained part of the gap in Table A2 $(-0.027)$ indicates that the raw gender wage differences cannot be explained by men's better characteristics. According to the available information, on average, women have better characteristics than men, so the adjusted gender wage gap is higher than the unadjusted one and estimated at $16.3 \%$. Similarly to the trends for the unadjusted gap, the explained part and the adjusted wage gap (both overall and by country) vary very little over time (Figure 1 and Table A3). In most Central and Eastern European economies (Lithuania, Slovenia, Poland, Latvia, Croatia, Hungary, Bulgaria and to a lesser extent in the Czech Republic and Slovakia) but also in Portugal and Denmark, the explained part is negative, signalling better labour market characteristics for women. On the other hand, in most Western economies (Germany, Austria, UK, France, the Netherlands and Finland), the explained part is positive, indicating that men have better labour market characteristics than women.

Both the explained and the unexplained part of the gap can be further disaggregated into the contributions of individual predictors, as the total of each component is the sum of the individual contributions (Jann, 2008). This piece of information is reported in the bottom part of Table A2. It reveals that the negative sign of the explained part of the gap is the result of two groups of factors with opposing effects. 
The first one includes the labour market characteristics that are in favour of women. They, on average, work in better-paid occupations, have higher levels of education and are on average older then employed men. The second group of factors consists of the characteristics that describe male advantages in the labour market. Men, on average, work in better-paid sectors, more frequently in larger companies and are employed more on permanent and full-time contracts. The main driver of this advantage for men is the fact that they work more frequently in better-paid sectors. This difference, ceteris paribus, explains $13 \%$ of the unadjusted wage gap (0.018 of 0.136 , on average for all years) and increases significantly over time: from $10.3 \%$ (0.014 of 0.136$)$ in 2010 to $15.3 \%(0.021$ of 0.137$)$ in 2013 , indicating that the impact of sectorial segregation on the gender wage gap became more pronounced.

\section{Fiscal consolidation programmes in EU-28: data, measures and descriptive evidence}

\subsection{Data and indicators}

The main aim of the paper is to assess the impact of fiscal consolidation programmes on gender wage inequality. To identify and quantify austerity measures, we adopt the conventional approach based on the use of the cyclically adjusted primary balance (CAPB). Changes in CAPB have been extensively used in the literature to identify fiscal consolidation episodes; earlier studies (e.g. Alesina and Perotti, 1995, 1997; Alesina et al., 1998) made use of the so-called Blanchard index (calculated assuming unchanged unemployment rate with respect to the previous year). More recent contributions (e.g. Tsibouris et al., 2006; Molnar, 2012; Perivier, 2018; Campos et al., 2017) prefer CAPB-based measures, acknowledging CAPB shortcomings which are primarily related to the fact that CAPB might reflect one-offs (Koen and van den Noord, 2005), growth surprises (Larch and Salto, 2005) and fluctuations on the revenue side due to asset price dynamics (Girouard and Price, 2004). As explained by Gujardo et al. (2014), changes in cyclically adjusted fiscal variables might also incorporate developments affecting total output that are not related to discretionary policy changes. In analyses aimed at identifying the expansionary/contractionary effects of fiscal consolidations, this poses a serious identification issue: a boom in the stock market, for example, not only improves the CAPB but is also likely to boost consumption and investment, thereby downplaying the contractionary effects of fiscal consolidation. Similarly, the policy measure could be targeted at reducing the risk of overheating, posing a severe reverse causality issue. In order to overcome these shortcomings, the literature suggests an alternative approach, based on the identification of changes in fiscal policy direct from historical documents (e.g. Romer and Romer, 2010; Devries et al., 2011; Gujardo et al., 2014, and the references cited therein). In our case, the large number of countries/years considered limits the feasibility of this narrative approach; at the same time, the focus of our study (impact of fiscal consolidation on the gender wage gap rather than growth) lessens the importance of identification and reverse causality issues. To address the remaining concerns (distortionary effects of cut-offs), in accordance with the Organisation for Economic Co-operation and Development (OECD) definition of 'underlying primary balance', we adjust the CAPB for the effects of one-off budget operations (typical examples are tax amnesties 
or revenue from privatisations). Our source of data is the AMECO (2018) database, which provides EU countries with information on the structural (i.e. net of one-offs and temporary measures) balance of general government (excluding interest), with cyclical adjustment based on potential GDP excessive deficit procedure (see Mourre et al., 2003). Data for this measure of CAPB for the EU-28 countries is directly available on the AMECO website starting from 2010; for previous years, the datasets provide separated information on cyclically adjusted revenue and expenditure (excluding interest), but not on one-offs and temporary measures. However, since according to our conceptual framework, the effects of austerity measure on the gender wage gap might be lagged one or more years, we also need information on fiscal consolidations implemented prior to 2010 (see Section 5.3.1). We therefore reconstructed the CAPB change using the data on one-off measures derived from OECD (2018) to correct the cyclically adjusted revenue and expenditure data provided in AMECO for the years 2006-09.

\subsection{Fiscal consolidation and the gender wage gap in the EU-28: preliminary evidence}

The geography of austerity in the years of the crisis in the EU-28 countries is illustrated in Table A4; the table describes the annual change of the CAPB over the period 200713. Despite its limitations, the CAPB approach is able to provide a picture of austerity in Europe largely consistent with existing empirical evidence (e.g. Theodoropoulou and Watt, 2011; Addabbo et al., 2015; Rubery, 2015). Table A4 confirms that, starting from 2009 but especially in the following years, most countries adopted fiscal consolidation measures. Particularly sharp reductions of government deficit were implemented in Greece, Spain, Portugal, Ireland, Czech Republic, Romania, Latvia and Slovenia. On the other hand, countries like Finland and Sweden did not introduce any fiscal adjustments. The diagrams in Figure 2 report the cumulated change of the CAPB over threeyear periods, from 2007 to 2013. This measure, as opposed to the annual change, is able to provide a more illustrative picture of the implementation of fiscal adjustment; a reduction of government deficit in one year might indeed be compensated (and therefore its effects partially neutralised) by a surplus in the following years. A cumulative index therefore provides a more robust identification of austerity measures of a structural nature. The diagrams in Figure 2 clearly show how the situation evolved over the period considered, with a growing number of countries moving towards the implementation of more or less severe government balance consolidation plans.

Figure 3 provides a first snapshot of the existence of the relationship of interest to the paper. Each panel plots the relationship between the adjusted gender wage gap in year $t$ and the cumulative change in CAPB from year $t-1$ to year $t-3$. As explained in detail in Section 5.3, the use of lags for policy/institutional variables is a common practice in the literature and is motivated, among other things (e.g. potential risks of endogeneity), by the fact that the effects of policies/reforms are not immediate and take time to unfold. In all panels in Figure 3, a positive relation can be observed (as approximated by the regression line) between austerity and gender wage inequality, although the correlation coefficient is statistically significant in only two years (out of four). The relationship depicted in the diagrams is by its nature inconclusive, since besides the potential role of austerity, many country-level factors could impact the gender gap. For this reason, we have to undertake some methodological refinements, described in the following section. Nonetheless, the results displayed in Figure 3 corroborate the idea of austerity being associated with a deterioration in gender equality. 

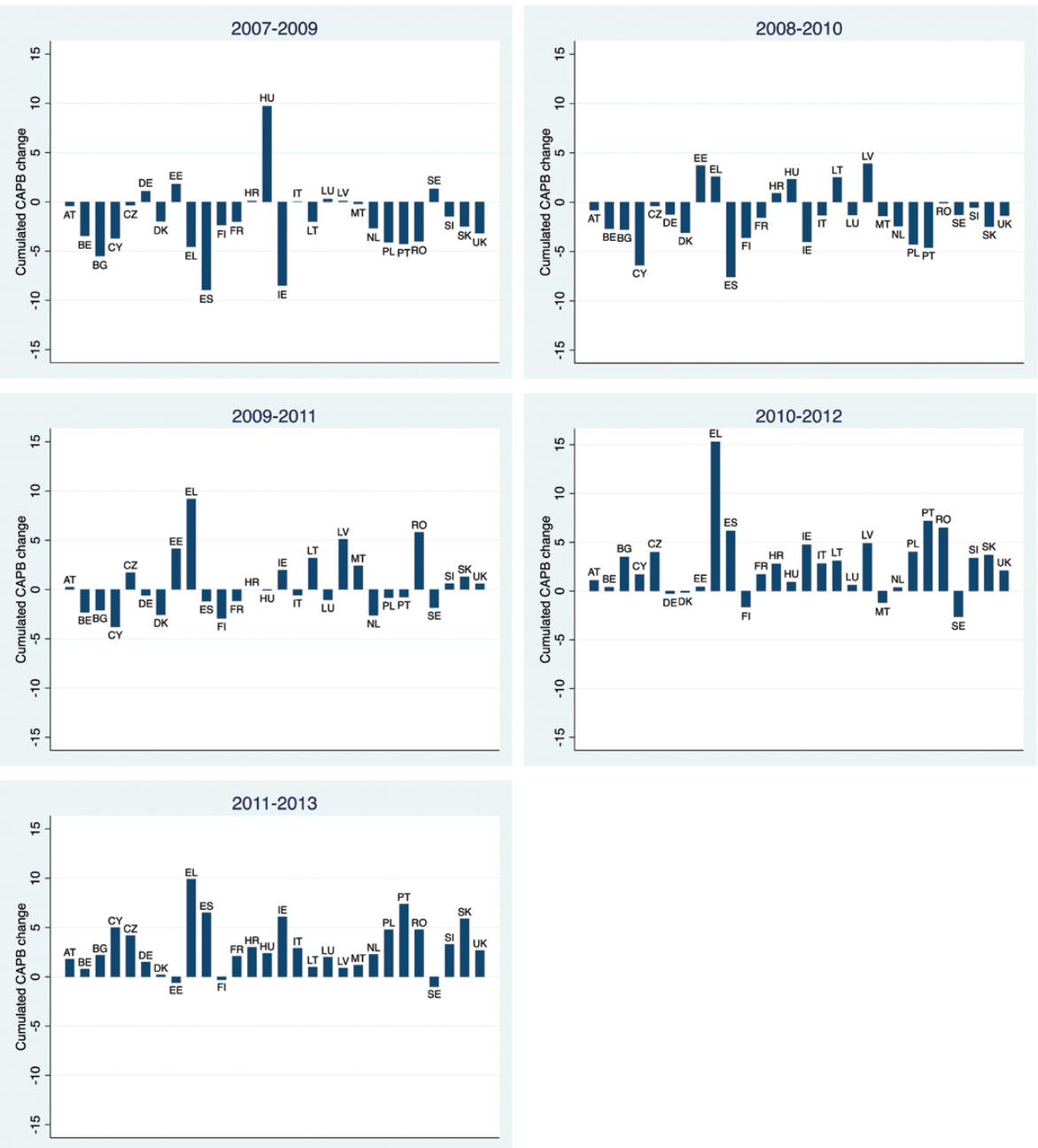

Note: Our elaborations on AMECO and OECD (2016) data; $C A P B=$ cyclically adjusted primary balance; for the country acronyms see Table A3.

Fig. 2. Austerity plans in EU-28 countries, 2007-13 (three years' cumulative CAPB changes).

\section{Austerity and gender wage inequality}

\subsection{Baseline empirical framework}

The starting point for the identification of the impact of austerity on the gender wage gap is the estimation of a wage equation, in which the log hourly wage (lhwage) is explained by a set of observable characteristics of the worker and of her/his employment position.

The microeconomic model of the wage determinants relies on the human capital approach as the theoretical basis for the earnings function (Mincer, 1958; Becker, 1964). Higher wages are associated first of all with higher formal education attained and informal skills accumulated through longer working experience (both general or firm-/sector-specific). As explained in Section 3.1, while we have detailed information 

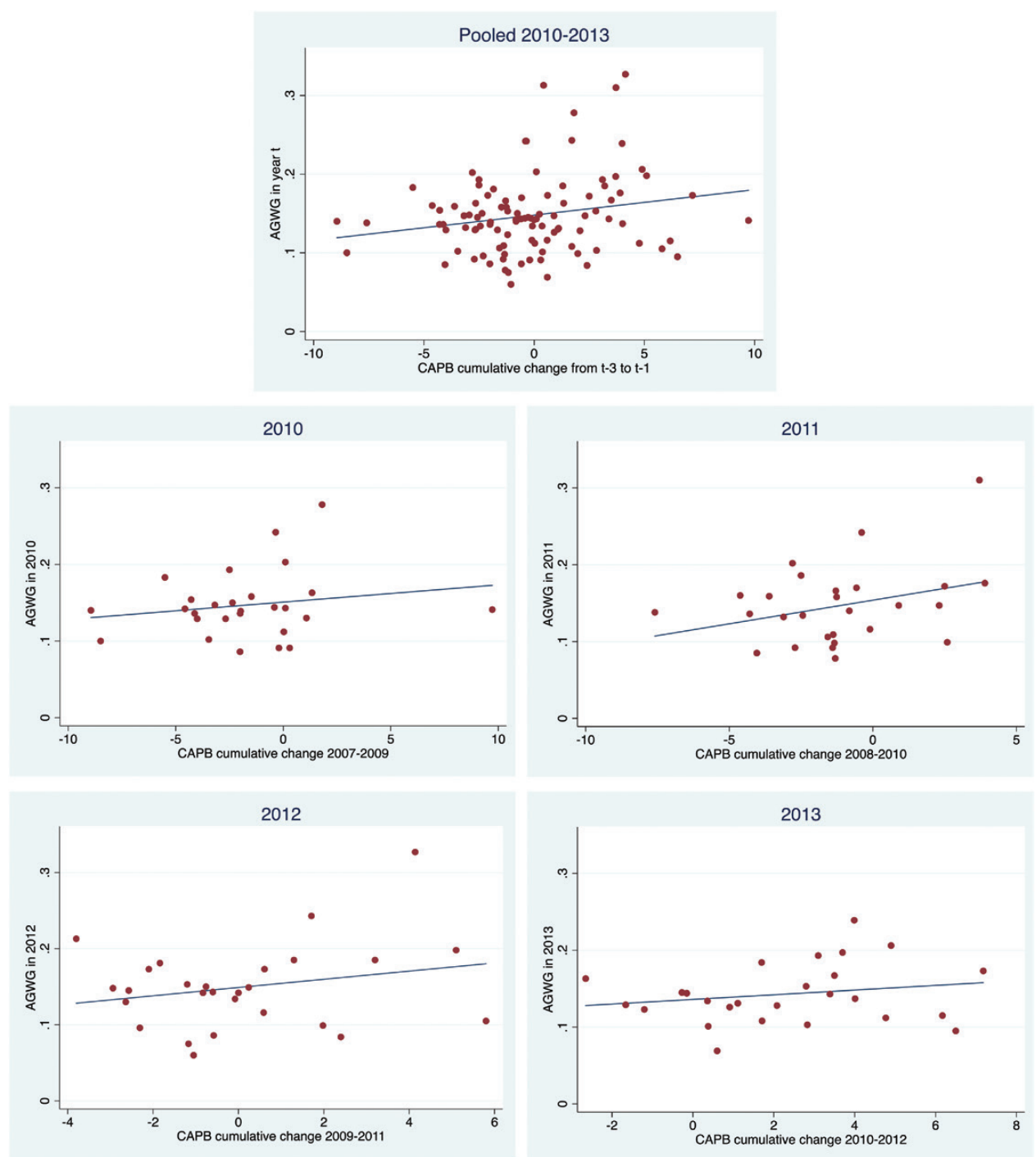

Note: Our elaborations on EU-SILC; AMECO and OECD (2016) data; AGWG = Adjusted gender wage gap; $C A P B=$ cyclically adjusted primary balance.

Fig. 3. Adjusted gender wage gap and austerity plans.

on education levels, we can only use the variable 'age' as a control for experience (as usual, included in linear and quadratic terms). The other explanatory variables refer and control for a large set of personal and job characteristics (see Section 3.1 and Table A1).

This wide range of information allows interpreting the gender dummy variable (female) as a proxy measure of the discrimination effect due to gender, once all remaining (observable) characteristics are controlled for (Newell and Reilly, 2001; Perugini and Selezneva, 2015). This approach, as any other relying on a statistical residual, is exposed to the question of whether all the necessary independent variables were 
included in the regression. If some factors are not measurable or not accountable for (say, job tenure) and, for example, men are better endowed than women with respect to those omitted variables, this would overestimate discrimination. Conversely, if some of the factors which are controlled for in such regressions, like occupation and industry of employment, in themselves describe a form of discrimination, then the coefficient from the equation would underestimate the discrimination.. However, as Blau and Kahn (2000) explain, results obtained using such approaches may nonetheless be instructive, if carefully interpreted in the awareness of the information included in the discrimination coefficient.

The baseline empirical model (for a pooled country/year sample) for the estimation of adjusted gender wage gap reads:

$$
\text { lhwage }_{i k t}=\text { Cons }+\alpha X_{i k t}+\beta_{1} \text { female }_{i k t}+\lambda_{k t}+v_{i k t}
$$

where subscripts $i, k$ and $t$ denote individuals, countries and years, respectively; $X$ is the regressor matrix and $\alpha$ the vector of associated coefficients. The coefficient of the gender dummy, $\beta_{1}$, measures the adjusted gender wage gap; $\lambda_{k t}$ denotes country-byyear dummies and $v$ is a mean-zero error term. The presence of distinct country-year intercepts addresses the issue related to the multilevel data structure, in which individual observations are nested within the country level (see Bryan and Jenkins, 2013).

\subsection{Differences-in-differences approach}

5.2.1 Methods and empirical models. To estimate the impact of austerity measures on the adjusted gender wage gap, we rely in the first instance on the differences-in-differences approach, that is specifically designed and extensively used for impact evaluation analysis. The intuition behind this approach is to compare the changes in the outcome over time of the group that was treated with some programme or policy-the treatment group (TG) — and the group that was not - the control group (CG). By making use of the same observations in two time periods (longitudinal data), the difference in the gender pay gap is free from the bias caused by gender differences in observed or unobserved characteristics.

For the implementation of this part of the analysis, we rely on the longitudinal version of the EU-SILC database, which is a four years rotational panel, with reference years 2010-13 (EU-SILC Longitudinal UDB 2014 - revision 2 of March 2017). By its own nature (rotational design and attrition), the use of the longitudinal dataset limits the number of observations to those available in both the initial (2010) and the final year (2013) of the period considered. In addition, not all variables provided in the EU-SILC cross-section sample are available in the panel dataset: in our case, we could not include the sector of employment, the size of the employer and the information about part-time/full-time jobs.

As for the country coverage of the analysis, the formation of the two groups (TG and CG) implied excluding some countries (besides Germany and Croatia, which are not included in the EU-SILC longitudinal dataset). The assumptions behind the method's identification approach demand first of all that all countries belonging to the two groups were not exposed to a treatment (in our case, sizable austerity measures) that could have shaped their gender wage gap observed in the initial year (2010 in our case). As a result, based on the data in Table A4, we excluded Estonia, Hungary, 
Lithuania, Luxemburg, Latvia, Malta, Cyprus and Italy. Based on the same information, we then identified the CG countries as those that did not implement austerity measures in the period 2010-12. Belgium, Denmark, Finland, Sweden and Poland belong to this group (CG). Another crucial condition for identification is that the countries included in the two groups experienced a similar trend in the variable of interest before the beginning of the period of analysis. According to the data provided by Eurostat, ${ }^{6}$ in all our CG countries (with the partial exception of Belgium), the gender wage gap declined in the period 2006-10; the EU countries with a similar trend and which implemented austerity programmes between 2010 and 2012 (our TG) are the Czech Republic, Ireland, Spain, Greece and Portugal.

Based on Angrist and Pischke (2009), we adapt the differences-in-differences approach for our purpose, in which the variable on which the effect of the treatment is assessed is not a wage level (as in the case of the reference work by Card and Krueger, 1994) but a wage gap. Our empirical model therefore reads:

$$
\begin{aligned}
\text { lhwage }_{i k t}= & \text { Cons }+\alpha X_{i k t}+\beta_{1} \text { female }_{i k t}+\beta_{2} \text { female }_{i k t} \cdot T_{2013}+\beta_{3} \text { female }_{i k t} \cdot T G_{k} \\
& +\beta_{4} \text { female }_{i k y} \cdot T_{2013} \cdot T G_{k}+\lambda_{k t}+v_{i k t}
\end{aligned}
$$

where $T_{2013}$ is a time dummy variable for the final year (2013) and TG is a dummy variable (at country level) which identifies the treated group (i.e. countries in which an austerity plan was implemented between 2010 and 2012). In such a model, following Angrist and Pischke (2009), $\beta_{1}$ is the gender wage gap in the CG countries in 2010; $\beta_{2}$ is the change in the gender wage gap for the CG between 2010 and $2013 ; \beta_{3}$ is the difference in gender wage gap in 2010 between the TG and the CG; and $\beta_{4}$ is the difference between the TG and the CG in the gender wage gap change between 2010 and 2013 and therefore the differences-in-differences coefficient that identifies the effect of the treatment.

An important empirical aspect that needs to be carefully addressed, already mentioned and dealt with in Section 3.2, refers to the possible estimation bias due to sample selection. All our empirical models are therefore estimated using a Heckman (1979) correction, as done for the Blinder-Oaxaca decomposition.

5.2.2 Results. The results of the estimation of equation (3) are reported in Table 1. Column 1 reports the baseline estimation in which the TG is composed of the Czech Republic, Ireland, Spain and Greece and the CG comprises Belgium, Denmark, Finland, Sweden and Poland. Columns 2 and 3 show how outcomes are robust to marginal alterations in the two groups. The estimates in column 2 exclude Belgium from the CG, since it had a slightly different gender wage gap trend prior to 2010 compared to the remaining countries. In column 3, the TG is augmented with Portugal, which had a slightly increasing trend (as opposed to a decreasing one).

In all estimations, the differences-in-differences term $\beta_{4}$ is negative and statistically significant. This indicates that in the countries in which austerity plans were implemented, the gender wage gap increased significantly, while in the CG countries such a change did not occur ( $\beta_{3}$ is positive but not statistically significant).

The estimated coefficients of the remaining explanatory variables indicate, as expected, that wages increase with age, education and better health conditions;

\footnotetext{
${ }^{6}$ Table [tsdsc340] - gender pay gap in unadjusted form, retrieved from https://ec.europa.eu/eurostat/web/ products-datasets/-/SDG_05_20 (last accessed 19/10/2018).
} 
Table 1. Austerity and gender wage gap, differences-in-differences estimation

(1)

\begin{tabular}{lccc}
\hline Female & $-0.181^{\star \star \star}$ & $-0.166^{\star \star \star}$ & $-0.173^{\star \star \star}$ \\
Female & $(0.018)$ & $(0.019)$ & $(0.019)$ \\
& $0.039^{\star}$ & 0.028 & 0.028 \\
Female 2013 TG & $(0.022)$ & $(0.024)$ & $(0.024)$ \\
Female TG $^{\star}$ year 2013 & 0.024 & 0.020 & 0.016 \\
Married & $(0.025)$ & $(0.026)$ & $(0.025)$ \\
& $-0.081^{\star \star}$ & $-0.071^{\star \star}$ & $-0.066^{\star \star}$ \\
Age & $(0.034)$ & $(0.035)$ & $(0.032)$ \\
& -0.012 & -0.010 & $-0.017^{\star}$ \\
Age & $(0.009)$ & $(0.010)$ & $(0.009)$ \\
& $0.123^{\star \star}$ & 0.011 & 0.066 \\
Health status & $(0.048)$ & $(0.050)$ & $(0.048)$ \\
Secondary education & -0.001 & $0.011^{\star}$ & 0.005 \\
& $(0.005)$ & $(0.006)$ & $(0.005)$ \\
Tertiary education & $-0.013^{\star \star}$ & -0.001 & $-0.017^{\star \star \star}$ \\
& $(0.006)$ & $(0.006)$ & $(0.006)$ \\
Permanent & $0.046^{\star \star}$ & $0.041^{\star}$ & $0.076^{\star \star \star}$ \\
& $(0.022)$ & $(0.023)$ & $(0.020)$ \\
Urban & $0.056^{\star \star}$ & 0.040 & $0.078^{\star \star \star}$ \\
& $(0.023)$ & $(0.025)$ & $(0.022)$ \\
Constant & $0.458^{\star \star \star}$ & $0.450^{\star \star \star}$ & $0.441^{\star \star \star}$ \\
& $(0.017)$ & $(0.017)$ & $(0.016)$ \\
Observations & $0.048^{\star \star \star}$ & $0.039^{\star \star \star}$ & $0.043^{\star \star \star}$ \\
Adjusted $R^{2}$ & $(0.009)$ & $(0.009)$ & $(0.009)$ \\
& $1.391^{\star \star \star}$ & $1.593^{\star \star \star}$ & $1.534^{\star \star \star}$ \\
\hline
\end{tabular}

Notes: All estimations include country/year and occupation dummies; sample selection correction. Clustered SEs in parenthesis. See Table A1 for variable and acronym descriptions. The coefficient of 'Female ${ }^{\star} \mathrm{TG}^{\star}$ year 2013' measures: [(AGWG $\left.\left.13-\mathrm{AGWG}_{10}\right)_{\mathrm{TG}}-\left(\mathrm{AGWG}_{13}-\mathrm{AGWG}_{10}\right)_{\mathrm{CG}}\right]$. Columns: (1) treatment group: CZ, IE, ES, EL; control group: BE, DK, FI, SE, PL. (2) treatment group: CZ, IE, ES, EL; control group: DK, FI, SE, PL. (3) treatment group: CZ, IE, ES, EL, PT; control group: BE, DK, FI, SE, PL.

Significance at the ${ }^{\star} 10 \%, \star \star 5 \%$ and ${ }^{\star \star \star} 1 \%$ level.

remunerations are also higher in urban areas and for permanent positions. The controls for occupations provide the expected hierarchy of coefficients (not reported for the sake of brevity, but available upon request).

The results of the impact of austerity are confirmed if we look at the changes in the adjusted gender wage gap over time (from 2010 to 2013) within the two groups separately (Table A5). In all estimations, the gender gap increases in 2013 compared to 2010 for the TG, contrary to what happened for the CG, in which the change over the four years is not statistically significant.

\subsection{Country fixed-effects model}

The differences-in-differences approach allows only a limited coverage of the analysis due to data constraints, in terms of both individuals and countries. In this section, we use an alternative empirical strategy that, despite sub-optimal for the purpose of the 
analysis, allows extending the empirical analysis to all EU-28 countries. This is also functional to test whether the main conclusion reached (austerity increasing gender wage inequality) is robust to a different method and sample.

5.3.1 Methods and empirical models. In the simplest, baseline empirical pooled model described in equation (2), the individual effects are constrained to be equal across countries but they can be allowed to differ by interacting subsets of individual-level characteristics with the country dummies. The use of country fixed effects obviously prevents the inclusion of additional country-level predictors in the empirical model, since the country intercepts already fully encapsulate cross-country differences (Snijders and Bosker, 1999). However, as done for example in Perugini and Selezneva (2015), country-level variables can be interacted with individual-level variables so as to obtain the additional effect that a country-level factor produces on the main (individual-level) effect. In our case, the interaction of country-level austerity indicators (AUS) with the gender dummy allows estimating the impact of austerity on the gender gap. Equation (4) describes this augmented empirical model, which can be estimated on the EU-28 sample obtained by pooling the county/year cross-sections (28 countries, 4 years):

$$
\text { lhwage }_{i k t}=\text { Cons }+\alpha X_{i k t}+\beta_{1} \text { female }_{i k t}+\beta_{2} \text { female }_{i k t} \cdot A U S_{k t}+\lambda_{k t}+v_{i k t}
$$

where all variable and parameters correspond to those described for equation (2) and the coefficient $\beta_{2}$ measures the impact of austerity on the adjusted gender gap.

As customary in the literature (Bassanini et al., 2009; Bourlès et al., 2012), the policy/institutional variables (AUS in our case) are lagged in order to alleviate endogeneity issues and to account for the fact that the implementation of policies/reforms take time to become effective. In order to test the robustness of our results, we use various measures and lags (see Table A1 for their definition).

We first of all estimate equation (4) using as austerity indicator the annual CAPB change, lagged either one (AUS_L1), two (AUS_L2) or three years (AUS_L3). Hence, for example in the case of one-year lag, for the data referring to 2010, the relevant austerity measure is the CAPB change in 2009; for the data referring to 2011, the CAPB change in 2010, and so on. In order to test whether a threshold effect exists (i.e. only changes large enough are able to produce visible effects), we also estimate equation (4) using as AUS a dummy variable (AUS_d) that is 1 if the annual change in CAPB exceeds $0.5 \%$ and 0 otherwise. Robustness checks are run for different thresholds (CAPB change $>0$ or $>1 \%$ ). Following Alesina et al. (2015), we also distinguish measures prevalently based on expenditure cuts or tax hikes. This is done by decomposing the CAPB dummy variable into two dummies (TB_AUS_d and EB_AUS_d) that indicate whether the consolidation plan was (predominantly) tax-based (TB) or expenditure-based (EB). For each AUS_d = 1, TB_AUS_d was coded as 1 if the change in the cyclically adjusted structural revenues (as a \% of GDP) was higher than the change in the cyclically adjusted structural expenditures, and coded as 0 otherwise. EB_AUS_d was coded as 1 when TB_AUS_d equals 0 and as 0 when TB_AUS_d equals 1 . Lastly, we test for the possibility that fiscal consolidation/austerity plans (rather than one-year measures) could better describe the impact of austerity on the gender wage gap. We therefore build a cumulated CAPB variable (AUS_p - austerity plan) which, for the year $t$, is obtained as the sum of the CAPB change in years $t-1, t-2$ and $t-3$ (variable 
named AUS_p_3_L1). This captures the idea that the gender wage gap in 2010 is affected by the austerity measures implemented in the period 2007-09; the gender wage gap in 2011 by the austerity plan in 2008-10, and so on. As a robustness check, we use a similar variable but cumulating two years only (AUS_p_2_L1). As done for the annual CAPB changes, we transformed these variables into dummies, coding them as 1 if the cumulated CAPB exceeded $1 \%$ and 0 otherwise (AUS_p_3_d_L1 and AUS_p_2_d_L1). Robustness checks were run for different thresholds (cumulated CAPB $>0.5 \%$ and $>1.5 \%$ ). Again, we tested for the possible heterogeneous effects of austerity plans, constructing the two corresponding dummy variables (TB_AUS_p_d and EB_AUS_p_d).

5.3.2 Results. Tables 2, 3 and A6 report the estimates of the model described in equation (4); although not displayed, all models include sector and occupation dummies as well as country/year fixed effects. All models include the sample selection correction and are estimated pooling the $28 \mathrm{EU}$ countries and the four years (2010 -13).

The baseline estimation in column 1 in Table 2 shows that the average (adjusted) gender wage gap in the pooled sample is $16.3 \%$, which corresponds to the figure reported in the first column of Table A2 (the unexplained part of the gender wage gap). The coefficients of the remaining explanatory variables confirm the results presented in Table 1; the additional variables (available for the cross-section sample only) also provide interesting insights. Sector dummies (not reported in the tables but available upon request) are significant and consistent with wage differentials normally observed across industries; also, hourly wages are higher in larger firms and for part-time positions. This latter outcome might be due to the fact that in part-time jobs the monthly wage reduction is not proportional to the reduction in hours worked. As a consequence, on an hourly basis, part-time positions might be better remunerated. However, this interpretation is in contrast to the literature on productivity/wage penalties for part-time workers and the descriptive evidence from our sample, in which the raw difference between full-time and part-time positions is positive for the large majority of countries. It is, therefore, more likely that our result can be explained in view of the empirical evidence showing that the part/full-time wage difference tends to disappear once the effects of self-selection into different segments of the labour market and personal and job characteristics are controlled for (e.g. Rodgers, 2004). ${ }^{7}$ Our results also show that hourly wage declines both as health status deteriorates and for workers with a second job. The controls for occupation and sector provide the expected hierarchy of coefficients (not reported for the sake of brevity, but available upon request).

As far as the focus of our analysis is concerned, columns $2-4$ of Table 2 show that austerity measures implemented in years $t-1, t-2$ and $t-3$, respectively, exacerbate gender wage inequality, with increasing momentum as time proceeds. For example, a $1 \%$ increase in CAPB in year $t$-3 (AUS_L3) increases the gender wage gap by

\footnotetext{
7 As expected, part-time positions are more common for women and in certain sectors, such as hotels and restaurants and health and social services. When all these variables are included in the regressions, the full-time dummy captures the difference with part-time within each individual characteristics profile. It is, for example, sufficient to exclude the gender variable from the regression to obtain a positive and significant coefficient for the full-time variable. At the same time, the exclusion of the full-time dummy from the model only very marginally affects the results, especially those of interest here [the coefficient of 'female' in column 1 of Table 2 declines by $0.05 \%$ ]. Detailed results are available upon request.
} 
Table 2. Austerity and gender wage gap (yearly and cumulative CAPB changes), country fixedeffect estimation

\begin{tabular}{|c|c|c|c|c|c|c|}
\hline & (1) & (2) & (3) & (4) & (5) & (6) \\
\hline Female & $\begin{array}{c}-0.163^{\star \star \star} \\
(0.001)\end{array}$ & $\begin{array}{l}-0.162^{\star \star \star} \\
(0.001)\end{array}$ & $\begin{array}{l}-0.164^{\star \star \star} \\
(0.001)\end{array}$ & $\begin{array}{c}-0.166^{\star \star \star} \\
(0.001)\end{array}$ & $\begin{array}{c}-0.163^{\star \star \star} \\
(0.001)\end{array}$ & $\begin{array}{c}-0.164^{\star \star \star} \\
(0.001)\end{array}$ \\
\hline Female ${ }^{\star}$ AUS_L1 & & $\begin{array}{l}-0.001^{\star \star \star} \\
(0.001)\end{array}$ & & & & \\
\hline Female`AUS_L2 & & & $\begin{array}{c}-0.003^{\star \star \star} \\
(0.001)\end{array}$ & & & \\
\hline Female`AUS_L3 & & & & $\begin{array}{l}-0.004^{\star \star \star} \\
(0.001)\end{array}$ & & \\
\hline Female* AUS_p_2_L1 $^{\star}$ & & & & & $\begin{array}{l}-0.001^{\star \star \star} \\
(0.000)\end{array}$ & \\
\hline Female ${ }^{\star}$ AUS_p_3_L1 & & & & & & $\begin{array}{l}-0.001^{\star \star \star} \\
(0.000)\end{array}$ \\
\hline Married & $\begin{array}{l}0.030^{\star \star \star} \\
(0.001)\end{array}$ & $\begin{array}{l}0.030^{\star \star \star} \\
(0.001)\end{array}$ & $\begin{array}{l}0.030^{\star \star \star} \\
(0.001)\end{array}$ & $\begin{array}{l}0.030^{\star \star \star} \\
(0.001)\end{array}$ & $\begin{array}{l}0.030^{\star \star \star} \\
(0.001)\end{array}$ & $\begin{array}{l}0.030^{\star \star \star} \\
(0.001)\end{array}$ \\
\hline Age & $\begin{array}{l}0.224^{\star \star \star} \\
(0.006)\end{array}$ & $\begin{array}{l}0.219 \star \star \star \star \\
(0.006)\end{array}$ & $\begin{array}{l}0.224^{\star \star \star} \\
(0.006)\end{array}$ & $\begin{array}{l}0.223^{\star \star \star} \\
(0.006)\end{array}$ & $\begin{array}{l}0.223^{\star \star \star} \\
(0.006)\end{array}$ & $\begin{array}{l}0.223^{\star \star \star} \\
(0.006)\end{array}$ \\
\hline $\mathrm{Age}^{2}$ & $\begin{array}{l}-0.018^{\star \star \star} \\
(0.001)\end{array}$ & $\begin{array}{l}-0.017^{\star \star \star} \\
(0.001)\end{array}$ & $\begin{array}{l}-0.018^{\star \star \star} \\
(0.001)\end{array}$ & $\begin{array}{l}-0.018^{\star \star \star} \\
(0.001)\end{array}$ & $\begin{array}{l}-0.018^{\star \star \star} \\
(0.001)\end{array}$ & $\begin{array}{l}-0.018^{\star \star \star} \\
(0.001)\end{array}$ \\
\hline Health status & $\begin{array}{c}-0.015^{\star \star \star} \\
(0.001)\end{array}$ & $\begin{array}{l}-0.015^{\star \star \star} \\
(0.001)\end{array}$ & $\begin{array}{l}-0.015^{\star \star \star} \\
(0.001)\end{array}$ & $\begin{array}{l}-0.015^{\star \star \star} \\
(0.001)\end{array}$ & $\begin{array}{l}-0.015^{\star \star \star} \\
(0.001)\end{array}$ & $\begin{array}{l}-0.015^{\star \star \star} \\
(0.001)\end{array}$ \\
\hline Secondary education & $\begin{array}{l}0.083^{\star \star \star} \\
(0.002)\end{array}$ & $\begin{array}{l}0.082^{\star \star \star} \\
(0.002)\end{array}$ & $\begin{array}{l}0.083^{\star \star \star} \\
(0.002)\end{array}$ & $\begin{array}{l}0.082^{\star \star \star} \\
(0.002)\end{array}$ & $\begin{array}{l}0.083^{\star \star \star} \\
(0.002)\end{array}$ & $\begin{array}{l}0.083^{\star \star \star} \\
(0.002)\end{array}$ \\
\hline Tertiary education & $\begin{array}{l}0.216^{\star \star \star} \\
(0.002)\end{array}$ & $\begin{array}{l}0.214^{\star \star \star} \\
(0.002)\end{array}$ & $\begin{array}{l}0.216^{\star \star \star} \\
(0.002)\end{array}$ & $\begin{array}{l}0.215^{\star \star \star} \\
(0.002)\end{array}$ & $\begin{array}{l}0.216^{\star \star \star} \\
(0.002)\end{array}$ & $\begin{array}{l}0.216^{\star \star \star} \\
(0.002)\end{array}$ \\
\hline Full time & $\begin{array}{l}-0.037^{\star \star \star} \\
(0.002)\end{array}$ & $\begin{array}{l}-0.036^{\star \star \star} \\
(0.002)\end{array}$ & $\begin{array}{l}-0.036^{\star \star \star} \\
(0.002)\end{array}$ & $\begin{array}{l}-0.037^{\star \star \star} \\
(0.002)\end{array}$ & $\begin{array}{l}-0.036^{\star \star \star} \\
(0.002)\end{array}$ & $\begin{array}{l}-0.036^{\star \star \star} \\
(0.002)\end{array}$ \\
\hline Second job & $\begin{array}{l}-0.028^{\star \star \star} \\
(0.010)\end{array}$ & $\begin{array}{l}-0.029 \star \star \star \star \\
(0.010)\end{array}$ & $\begin{array}{l}-0.028^{\star \star \star} \\
(0.010)\end{array}$ & $\begin{array}{l}-0.028^{\star \star \star} \\
(0.010)\end{array}$ & $\begin{array}{l}-0.028^{\star \star \star} \\
(0.010)\end{array}$ & $\begin{array}{l}-0.028^{\star \star \star} \\
(0.010)\end{array}$ \\
\hline Permanent & $\begin{array}{l}0.115^{\star \star \star} \\
(0.002)\end{array}$ & $\begin{array}{l}0.115^{\star \star \star} \\
(0.002)\end{array}$ & $\begin{array}{l}0.115^{\star \star \star} \\
(0.002)\end{array}$ & $\begin{array}{l}0.115^{\star \star \star} \\
(0.002)\end{array}$ & $\begin{array}{l}0.115^{\star \star \star} \\
(0.002)\end{array}$ & $\begin{array}{l}0.115^{\star \star \star} \\
(0.002)\end{array}$ \\
\hline Firm size (11-49) & $\begin{array}{l}0.064^{\star \star \star} \\
(0.001)\end{array}$ & $\begin{array}{l}0.063^{\star \star \star} \\
(0.001)\end{array}$ & $\begin{array}{l}0.064^{\star \star \star} \\
(0.001)\end{array}$ & $\begin{array}{l}0.064^{\star \star \star} \\
(0.001)\end{array}$ & $\begin{array}{l}0.064^{\star \star \star} \\
(0.001)\end{array}$ & $\begin{array}{l}0.064^{\star \star \star} \\
(0.001)\end{array}$ \\
\hline Firm size (over 50) & $\begin{array}{l}0.151^{\star \star \star} \\
(0.001)\end{array}$ & $\begin{array}{l}0.151^{\star \star \star} \\
(0.001)\end{array}$ & $\begin{array}{l}0.151^{\star \star \star} \\
(0.001)\end{array}$ & $\begin{array}{l}0.151^{\star \star \star} \\
(0.001)\end{array}$ & $\begin{array}{l}0.151^{\star \star \star} \\
(0.001)\end{array}$ & $\begin{array}{l}0.151^{\star \star \star} \\
(0.001)\end{array}$ \\
\hline Urban & $\begin{array}{l}0.037^{\star \star \star} \\
(0.001)\end{array}$ & $\begin{array}{l}0.036^{\star \star \star} \\
(0.001)\end{array}$ & $\begin{array}{l}0.037^{\star \star \star} \\
(0.001)\end{array}$ & $\begin{array}{l}0.037^{\star \star \star} \\
(0.001)\end{array}$ & $\begin{array}{l}0.036^{\star \star \star} \\
(0.001)\end{array}$ & $\begin{array}{l}0.036^{\star \star \star} \\
(0.001)\end{array}$ \\
\hline Constant & $\begin{array}{l}1.925^{\star \star \star} \\
(0.017)\end{array}$ & $\begin{array}{l}1.937^{\star \star \star} \\
(0.017)\end{array}$ & $\begin{array}{l}1.491^{\star \star \star} \\
(0.017)\end{array}$ & $\begin{array}{l}1.918^{\star \star \star} \\
(0.017)\end{array}$ & $\begin{array}{l}1.924^{\star \star \star} \\
(0.017)\end{array}$ & $\begin{array}{l}1.921^{\star \star \star} \\
(0.017)\end{array}$ \\
\hline & 677,702 & 677,702 & 677,702 & 677,702 & 677,702 & 677,702 \\
\hline Adjusted $R^{2}$ & 0.696 & 0.695 & 0.696 & 0.696 & 0.696 & 0.696 \\
\hline
\end{tabular}

Notes: All estimations include sector, occupation and country/year dummies; sample selection correction. Clustered SEs in parenthesis. See Table A1 for variable and acronym descriptions.

Significance at the ${ }^{\star} 10 \%,{ }^{\star \star} 5 \%$ and ${ }^{\star \star \star} 1 \%$ level.

$0.4 \%$ in year $t$. A similar detrimental (and statistically significant) effect on gender equality is played by austerity plans ( $2 / 3$ years cumulated CAPB changes lagged one year, columns 5 and 6 ). As a first robustness check, but also in order to investigate the possibility that a dichotomic measure of austerity might provide clearer results, 
Table 3. Austerity measures and gender wage gap (yearly and cumulative CAPB changes as a dummy variable), country fixed-effect estimation

\begin{tabular}{|c|c|c|c|c|c|}
\hline & (1) & (2) & (3) & (4) & (5) \\
\hline Female & $\begin{array}{c}-0.159^{\star \star \star} \\
(0.001)\end{array}$ & $\begin{array}{c}-0.158^{\star \star \star} \\
(0.001)\end{array}$ & $\begin{array}{c}-0.162^{\star \star \star} \\
(0.001)\end{array}$ & $\begin{array}{c}-0.159^{\star \star \star} \\
(0.001)\end{array}$ & $\begin{array}{c}-0.156^{\star \star \star} \\
(0.001)\end{array}$ \\
\hline Female ${ }^{\star}$ AUS_d_L1 & $\begin{array}{c}-0.008^{\star \star \star} \\
(0.002)\end{array}$ & & & & \\
\hline Female ${ }^{\star}$ AUS_d_L2 & & $\begin{array}{c}-0.018^{\star \star \star} \\
(0.002)\end{array}$ & & & \\
\hline Female*AUS_d_L3 & & & $\begin{array}{l}-0.008^{\star \star \star} \\
(0.002)\end{array}$ & & \\
\hline Female $^{\star}$ AUS_p_2_d_L1 & & & & $\begin{array}{c}-0.014^{\star \star \star} \\
(0.002)\end{array}$ & \\
\hline Female ${ }^{\star}$ AUS_p_3_d_L1 & & & & & $\begin{array}{c}-0.027^{\star \star \star} \\
(0.002)\end{array}$ \\
\hline Married & $\begin{array}{l}0.030^{\star \star \star} \\
(0.001)\end{array}$ & $\begin{array}{l}0.030^{\star \star \star} \\
(0.001)\end{array}$ & $\begin{array}{l}0.030^{\star \star \star} \\
(0.001)\end{array}$ & $\begin{array}{l}0.030^{\star \star \star} \\
(0.001)\end{array}$ & $\begin{array}{l}0.029^{\star \star \star} \\
(0.001)\end{array}$ \\
\hline Age & $\begin{array}{l}0.224^{\star \star \star} \\
(0.006)\end{array}$ & $\begin{array}{l}0.224^{\star \star \star} \\
(0.006)\end{array}$ & $\begin{array}{l}0.224^{\star \star \star} \\
(0.006)\end{array}$ & $\begin{array}{l}0.224^{\star \star \star} \\
(0.006)\end{array}$ & $\begin{array}{l}0.224^{\star \star \star} \\
(0.006)\end{array}$ \\
\hline $\mathrm{Age}^{2}$ & $\begin{array}{c}-0.018^{\star \star \star} \\
(0.001)\end{array}$ & $\begin{array}{l}-0.018^{\star \star \star} \\
(0.001)\end{array}$ & $\begin{array}{l}-0.018^{\star \star \star} \\
(0.001)\end{array}$ & $\begin{array}{c}-0.018^{\star \star \star} \\
(0.001)\end{array}$ & $\begin{array}{l}-0.018^{\star \star \star} \\
(0.001)\end{array}$ \\
\hline Health status & $\begin{array}{c}-0.015^{\star \star \star} \\
(0.001)\end{array}$ & $\begin{array}{l}-0.015^{\star \star \star} \\
(0.001)\end{array}$ & $\begin{array}{c}-0.015^{\star \star \star} \\
(0.001)\end{array}$ & $\begin{array}{c}-0.015^{\star \star \star} \\
(0.001)\end{array}$ & $\begin{array}{c}-0.015^{\star \star \star} \\
(0.001)\end{array}$ \\
\hline Secondary education & $\begin{array}{l}0.083^{\star \star \star} \\
(0.002)\end{array}$ & $\begin{array}{l}0.083^{\star \star \star} \\
(0.002)\end{array}$ & $\begin{array}{l}0.083^{\star \star \star} \\
(0.002)\end{array}$ & $\begin{array}{l}0.083^{\star \star \star} \\
(0.002)\end{array}$ & $\begin{array}{l}0.083^{\star \star \star} \\
(0.002)\end{array}$ \\
\hline Tertiary education & $\begin{array}{l}0.216^{\star \star \star} \\
(0.002)\end{array}$ & $\begin{array}{l}0.216^{\star \star \star} \\
(0.002)\end{array}$ & $\begin{array}{l}0.216^{\star \star \star} \\
(0.002)\end{array}$ & $\begin{array}{l}0.216^{\star \star \star} \\
(0.002)\end{array}$ & $\begin{array}{l}0.216^{\star \star \star} \\
(0.002)\end{array}$ \\
\hline Full time & $\begin{array}{l}-0.036^{\star \star \star} \\
(0.002)\end{array}$ & $\begin{array}{l}-0.036^{\star \star \star} \\
(0.002)\end{array}$ & $\begin{array}{l}-0.036^{\star \star \star} \\
(0.002)\end{array}$ & $\begin{array}{l}-0.036^{\star \star \star} \\
(0.002)\end{array}$ & $\begin{array}{l}-0.035^{\star \star \star} \\
(0.002)\end{array}$ \\
\hline Second job & $\begin{array}{c}-0.028^{\star \star \star} \\
(0.010)\end{array}$ & $\begin{array}{l}-0.028^{\star \star \star} \\
(0.010)\end{array}$ & $\begin{array}{c}-0.028^{\star \star \star} \\
(0.010)\end{array}$ & $\begin{array}{l}-0.028^{\star \star \star} \\
(0.010)\end{array}$ & $\begin{array}{c}-0.028^{\star \star \star} \\
(0.010)\end{array}$ \\
\hline Permanent & $\begin{array}{l}0.115^{\star \star \star} \\
(0.002)\end{array}$ & $\begin{array}{l}0.115^{\star \star \star} \\
(0.002)\end{array}$ & $\begin{array}{l}0.115^{\star \star \star} \\
(0.002)\end{array}$ & $\begin{array}{l}0.115^{\star \star \star} \\
(0.002)\end{array}$ & $\begin{array}{l}0.115^{\star \star \star} \\
(0.002)\end{array}$ \\
\hline Firm size (11-49) & $\begin{array}{l}0.064^{\star \star \star} \\
(0.001)\end{array}$ & $\begin{array}{l}0.064^{\star \star \star} \\
(0.001)\end{array}$ & $\begin{array}{l}0.064^{\star \star \star} \\
(0.001)\end{array}$ & $\begin{array}{l}0.064^{\star \star \star} \\
(0.001)\end{array}$ & $\begin{array}{l}0.064^{\star \star \star} \\
(0.001)\end{array}$ \\
\hline Firm size (over 50) & $\begin{array}{l}0.151^{\star \star \star} \\
(0.001)\end{array}$ & $\begin{array}{l}0.151^{\star \star \star} \\
(0.001)\end{array}$ & $\begin{array}{l}0.151^{\star \star \star} \\
(0.001)\end{array}$ & $\begin{array}{l}0.151^{\star \star \star} \\
(0.001)\end{array}$ & $\begin{array}{l}0.151^{\star \star \star} \\
(0.001)\end{array}$ \\
\hline Urban & $\begin{array}{l}0.037^{\star \star \star} \\
(0.001)\end{array}$ & $\begin{array}{l}0.037^{\star \star \star} \\
(0.001)\end{array}$ & $\begin{array}{l}0.037^{\star \star \star} \\
(0.001)\end{array}$ & $\begin{array}{l}0.037^{\star \star \star} \\
(0.001)\end{array}$ & $\begin{array}{l}0.037^{\star \star \star} \\
(0.001)\end{array}$ \\
\hline Constant & $\begin{array}{l}1.923^{\star \star \star} \\
(0.017)\end{array}$ & $\begin{array}{l}1.921^{\star \star \star} \\
(0.017)\end{array}$ & $\begin{array}{l}1.924^{\star \star \star} \\
(0.017)\end{array}$ & $\begin{array}{l}1.921^{\star \star \star} \\
(0.017)\end{array}$ & $\begin{array}{l}1.920^{\star \star \star} \\
(0.017)\end{array}$ \\
\hline Observations & 677,702 & 677,702 & 677,702 & 677,702 & 677,702 \\
\hline Adjusted $R^{2}$ & 0.696 & 0.696 & 0.696 & 0.696 & 0.696 \\
\hline
\end{tabular}

Notes: All estimations include sector, occupation and country/year dummies; sample selection correction. Clustered SEs in parenthesis. See Table A1 for variable and acronym descriptions.

Significance at the ${ }^{\star} 10 \%, \star \star 5 \%$ and ${ }^{\star \star \star} 1 \%$ level.

in Table 3 we replace the continuous measures of CAPB changes with the dummy variables AUS_d and AUS_p_d described in Section 5.3.1 (see also Table A1 for the definition of variables and acronyms). Results are in line with those shown in Table 2 , that is, austerity increases the gender gap, but the size of the effect is remarkably larger, especially when austerity is identified as a multi-annual consolidation plan. 
A cumulative CAPB change larger than $1 \%$ in the preceding two (AUS_p_2_d_L1) and three (AUS_p_3_d_L1) years increases the gender wage gap by $1.4 \%$ and $2.7 \%$, respectively. This evidence not only supports the view that austerity exacerbates gender gap inequality, but also indicates that sizable austerity plans are able to exert a conspicuous and increasing effect over time. Robustness checks carried out altering the threshold of the dummy variables (AUS_d $>0 \%$ and AUS_d $>1 \%$ for the annual CAPB change; AUS_p_d $>0.5 \%$ and AUS_p_d $>1.5 \%$ for the cumulated CAPB change) confirm the outcomes shown in Table 3 (not reported here but available upon request).

In order to investigate whether there is a difference between the impacts of tax-based and expenditure-based austerity plans on gender wage gap, in Table A6, we replace the dummies used in Table 3 with those calculated separately for tax and expenditure changes (TB_AUS_p_d and EB_AUS_p_d). Outcomes confirm the detrimental role of austerity on gender equality (therefore confirming the robustness of our findings) and indicate that the effect of expenditure cuts tends to be larger than that of tax hikes, although their difference is statistically significant in only one case.

\section{Austerity and gender segregation}

\subsection{Methods and empirical models}

In order to investigate whether austerity measures impact on the horizontal dimension of gender inequality, we also estimated the relationship between fiscal consolidation and the probability of women being employed in sectors with different average wage levels. Our choice of sectors as a dimension of gender segregation is dictated by the fact that industries better reflect dynamics of horizontal segregation, occupations being at least partly the result of decisions related to education, personal characteristics and skills (rather than of a sectorial choice). In addition, as emerged in the Blinder-Oaxaca decomposition presented in Section 3.2, gender asymmetries in occupations do not explain the gender wage gap. On the contrary, sectorial segregation explains on average $13 \%$ of the wage gap, since men disproportionately work in better-paid sectors. From 2010 to 2013 , this share grew from $10 \%$ to $15 \%$ (see Section 3.2), which indicates that this dimension of gender inequality tends to be increasingly important.

Unfortunately, the unavailability of the information about sectors of employment in the longitudinal EU-SILC dataset prevents the implementation of a differences-indifferences approach similar to the one described in Section 5.2. Therefore, we rely again on a country fixed-effect model as in Section 5.3, applied on the pooled EU-28 sample.

To this end, as a preliminary step, we re-ranked the 13 sectors from the lowest to the highest average pay in each country/year. The 13 ordered sectors were rearranged into 5 ordered categories so as to have a balanced number of individuals. ${ }^{8}$ This ordered variable-sector(v), ranging from 1 to 5 -is then used to estimate the following ordered logit model:

$$
\operatorname{Sector}(\mathrm{v})_{i k t}=\alpha X_{i k t}+\beta_{1} \text { female }_{i k t}+\beta_{2} \text { female }_{i k t} \cdot A U S_{k t}+u_{k}+\lambda_{t}+u_{k} \cdot \lambda_{t}+v_{i k t}
$$

\footnotetext{
${ }^{8}$ Robustness checks were run reducing the number of ordered categories to 3 or keeping the 13 original sectors.
} 
where symbols and variables correspond to those described in equation (2). However, since the variables related to job positions (occupations, second job, part time, permanent employment, size of the firm) are to some extent a consequence of being employed in a given sector, we also run the same model excluding them from the set $X$ in order to check the robustness of our results. As explained in Cameron and Trivedi (2010), the signs of the regression parameters in equation (5) can be immediately interpreted as determining whether the latent dependent variable increases with the regressor. A positive coefficient indicates that the associated regressor decreases the probability of belonging to the lowest category (lowest pay sectors) and increases the probability of belonging to the highest category (highest pay sectors).

\subsection{Results}

Results of the estimation of equation (5) are reported in Table 4 (and Table A7) and confirm that women have a lower probability of being employed in high-paying sectors; in addition, they clearly suggest that the implementation of fiscal consolidation measures leads to a further decline in female workers' chances of being employed in better-paid sectors. If we distinguish the nature of austerity measures/plans (columns 3 and 4 of Table 4), the expenditure-based ones seem to exert a more detrimental role on gender wage inequality, via sectorial employment segregation adverse to women. This outcome is soundly confirmed by the evidence presented in Table A7, which differs from Table 4 in the exclusion of job-related control variables that might have captured some sectorial aspects. Further robustness checks were carried out, reducing the number of ordered sectors to 3 and increasing it to 13. Results, not displayed here but available upon request, unequivocally confirm that austerity further reduces women's chances of being employed in high-paid sectors.

\section{Discussion and final remarks}

The aim of this study is to provide evidence on the relationship between the implementation of austerity measures and gender inequality. While the existing literature offers a number of theoretical explanations as to how fiscal consolidation policies impact asymmetrically on women, empirical evidence not limited to pure descriptive methods is still very scanty. Moreover, many studies focus on the effect of fiscal contractionary policies on quantitative labour market aspects such as female employment, unemployment and activity rates, whereas their consequences for gender wage discrimination and horizontal segregation remain largely unexplored. In this paper, we tried to fill this gap by means of an empirical analysis employing EU-SILC microdata for the EU member states in the period 2010-13.

Our findings support, on different fronts, the idea that austerity is detrimental to gender equality. The first empirical evidence we provide is the existence of a positive relationship between the implementation of austerity measures and gender wage inequality when accounting for a wide (although not exhaustive) set of workers and jobs characteristics: in other words, austerity favours gender discrimination practices. We explain this result in the more general framework of statistical discrimination, rather than as related to the discriminatory tastes of employees, co-workers or customers (Becker, 1957). Statistical discrimination arises in the context of incomplete information, when employers, in the absence of information on individual counterparts, use 
Table 4. Austerity plans and sectoral gender segregation, country fixed-effect estimation

Dependent variable: sectors ordered by increasing average wage

Female

Female*p_AUS_2_d_L1

Female*p_AUS_3_d_L1

Female`EB_AUS_p_2_d_L1

Female*TB_AUS_p_2_d_L1

Female`EB_AUS_p_3_d_L1

Female*TB_AUS_p_3_d_L1

Married

Age

$\mathrm{Age}^{2}$

Health status

Secondary education

Tertiary education

Full time

Second job

Permanent

Firm size (11-49)

Firm size (over 50)

Urban

Cut 1

Cut 2

Cut 3

Cut 4

Test $\left(\chi^{2}\right)$ EB_AUS $=$ TB_AUS

Observations

Pseudo- $R^{2}$
(1)

(2)

(3)

(4)

$\begin{array}{lcc}-0.015^{\star \star} & -0.013^{\star \star} & -0.015^{\star \star} \\ (0.006) & (0.006) & (0.006) \\ -0.114^{\star \star \star} & & \\ (0.009) & & \\ & -0.144^{\star \star \star} & \\ & (0.010) & -0.177^{\star \star \star} \\ & (0.014) \\ & -0.076^{\star \star \star} \\ & (0.011)\end{array}$

$0.041^{\star \star \star}$

$(0.005)$

$(0.005)$

$0.561^{\star \star \star}$

(0.027)

$-0.054^{\star \star \star}$

$(0.003)$

$0.033^{\star \star \star}$

(0.003)

$0.275^{\star \star \star}$

$(0.007)$

$0.543^{\star \star \star}$

(0.010)

$0.069^{\star \star \star}$

(0.008)

$-0.155^{\star \star \star}$

(0.031)

$-0.005$

(0.007)

$0.473^{\star \star \star}$

(0.006)

$0.744^{\star \star \star}$

(0.006)

$-0.037^{\star \star \star}$

(0.005)

$1.137^{\star \star \star}$

(0.070)

$2.156^{\star \star \star}$

(0.070)

$3.189^{\star \star \star}$

(0.071)

$4.752^{\star \star \star}$

(0.071)

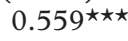

(0.027)

$-0.054^{\star \star \star}$

(0.003)

$0.033^{\star \star \star}$

(0.003)

$0.275^{\star \star \star}$

(0.007)

$0.543^{\star \star \star}$

(0.010)

$0.072^{\star \star \star}$

(0.008)

$-0.155^{\star \star \star}$

(0.031)

$-0.005$

(0.007)

$0.473^{\star \star \star}$

(0.006)

$0.744^{\star \star \star}$

(0.006)

$-0.037^{\star \star \star}$

(0.005)

$1.135^{\star \star \star}$

(0.070)

$2.154^{\star \star \star}$

(0.070)

$0.041^{\star \star \star}$

(0.005)

$0.561^{\star \star \star}$

(0.027)

$-0.054^{\star \star \star}$

(0.003)

$0.033^{\star \star \star}$

(0.003)

$0.275^{\star \star \star}$

(0.007)

$0.543^{\star \star \star}$

(0.010)

$0.071^{\star \star \star}$

(0.008)

$-0.155^{\star \star \star}$

(0.031)

$-0.005$

(0.007)

$0.473^{\star \star \star}$

(0.006)

$0.744^{\star \star \star}$

(0.006)

$-0.037^{\star \star \star}$

(0.005)

$1.137^{\star \star \star}$

(0.070)

$2.156^{\star \star \star}$

(0.070)

$3.190^{\star \star \star}$

$3.188^{\star \star \star}$

$4.751^{\star \star \star}$

(0.071)

677,702

0.0719
(0.071)

$4.753^{\star \star \star}$

(0.071)

$41.41^{\star \star \star}$

677,702

0.0719 $-0.162^{\star \star \star}$ (0.018)

$-0.137^{\star \star \star}$

(0.011)

$-0.013^{\star \star}$

(0.006)

$0.041^{\star \star \star}$

(0.005)

$0.559^{\star \star \star}$

(0.027)

$-0.054^{\star \star \star}$

(0.003)

$0.033^{\star \star \star}$

(0.003)

$0.274^{\star \star \star}$

(0.007)

$0.543^{\star \star \star}$

(0.010)

$0.073^{\star \star \star}$

(0.008)

$-0.154^{\star \star \star}$

(0.031)

$-0.005$

(0.007)

$0.473^{\star \star \star}$

(0.006)

$0.744^{\star \star \star}$

(0.006)

$-0.037^{\star \star \star}$

(0.005)

$1.135^{\star \star \star}$

(0.070)

$2.154^{\star \star \star}$

(0.070)

$3.188^{\star \star \star}$

$(0.070)$

$4.751^{\star \star \star}$

$(0.071)$

1.59

677,702

0.0719

Notes: All estimations include sector, occupation and country/year dummies; sample selection correction. Columns 2 and 4 also include occupation dummies. Clustered SEs in parenthesis. See Table A1 for variable and acronym descriptions.

Significance at the ${ }^{\star} 10 \%,{ }^{\star \star} 5 \%$ and ${ }^{\star \star \star} 1 \%$ level. 
group averages to predict the skill and productivity of individuals in a group (Phelps, 1972; Aigner and Cain, 1977). This leads to the 'rational' response of paying lower wages to individuals belonging to the more heterogeneous group with lower expected productivity. In our conceptual framework, austerity measures might have driven downwards employers' expectations of women's productivity. The extensive budget cuts to care services, described in Section 2, likely fed an expectation of lower availability, continuity and flexibility of female labour. Similarly, heavier family care loads (of children and the elderly), typically heaped disproportionately on women, probably decreased their ability to provide the expected level of effort on the job. Also, austerity measures often took the form of pension cuts, limited or frozen access to early retirement, and postponement of retirement age, all measures that are likely to have aggravated women's family workload by reducing their reliance on grandparents for childcare. Some measures introduced right at the end of our period of examination, such as the universal tax credit in UK, and intended to replace six different benefits, might contribute to decreasing labour market incentives for second earners in couples, most of them being women. As Adam and Browne (2013) show, the introduction of universal credit strengthens the incentive for couples to have one person in work rather than none, but weakens the incentive for both members of a couple to work.

Besides impacting directly on the pay that female workers are able to negotiate vis-àvis the employer, these mechanisms might explain the exacerbation of horizontal segregation that emerged in our analysis. Our second main result is indeed that austerity reduced the already low probability of women (compared to men) of being employed in high-paying sectors. This indicates a deterioration of women's capacity to attain high-paid job positions in general, on which the imposition of heavier family-related tasks poses relevant constraints. Jobs in high-paying sectors normally imply high flexibility and adaptability (time- and space-wise), and also long-term continuity on the job in order to accumulate the specific experience that complements formal education (see Perugini and Pompei, 2017). The inability of women to supply such assets in a context of decreasing provision of family care services may seriously impact their capacity to compete with men in attaining such jobs.

The third important piece of evidence we have obtained is that austerity impacts negatively on gender equality not only when it is based on expenditure cuts but also when it is based on tax hikes (although the effect tends to be quantitatively weaker). Higher taxation inevitably translates into lower individual and household disposable income. In a context of gender wage inequality and widespread budget cuts that generate an increasing need for unpaid family work, a reduction in household disposable income is likely to lead to a reinforcement of the male breadwinner model. The reduction of household disposable income might indeed drive division of labour within the family in favour of the breadwinner (most frequently the man) doing mostly paid work, with family care tasks becoming the responsibility of the lower-income recipient (normally the woman). These mechanisms might reinforce the patterns that feed the already described weaknesses in women's bargaining power and job positions.

Our study is one of the first attempts to provide quantitative evidence of the effects of austerity on gender wage inequality. A priority on our research agenda is to update the analysis as soon as microdata for the most recent years are available. Our results clearly show that the effects of fiscal consolidation on the gender gap take time to fully unfold; since the bulk of austerity measures were implemented in Europe after 2011, this means that further bad news is still to come. The implications of our results, if 
confirmed, will not be small. The ideology on which the desirability of austerity is based will, at the very least, need to add to the list of its side effects the worsening of one of the most unacceptable forms of inequality: that based on gender. Similarly, for European policymakers wishing to promote development patterns that are concerned with equity, the evidence presented here suggests that public budget balance consolidation has various consequences for gender inequality, which put at risk the little progress achieved to date.

\section{Bibliography}

Adam, S. and Browne, J. 2013. 'Do the UK Government's Welfare Reforms Make Work Pay?', Institute for Fiscal Studies, IFS Working Paper no. W13/26

Addabbo, T., Bastos, A., Casaca, S. F., Duvvury, N. and Ni Leime, A. 2015. Gender and labour in times of austerity: Ireland, Italy and Portugal in comparative perspective, International Labour Review, vol. 154, no. 4, 449-73

Aigner, D. and Cain, G. 1977. Statistics theories of discrimination in labor markets, Industrial and Labor Relations Review, vol. 30, 175-87

Alesina, A., Ardagna, S. and Galì, J. 1998. Tales of fiscal adjustment, Economic Policy, vol. 13, no. $27,487-545$

Alesina, A. and Ardagna, S. 2010. Large changes in fiscal policy: taxes versus spending, pp. 35-68 in Brown, J. (ed.), Tax Policy and the Economy, vol. 24, Ch. 2, Cambridge, MA, National Bureau of Economic Research

Alesina, A., Favero, C. and Giavazzi, F. 2015. The output effect of fiscal consolidation plans, Fournal of International Economics, vol. 96, S19-42

Alesina, A. and Perotti, R. 1995. Fiscal expansions and adjustments in OECD countries, Economic Policy, vol. 21, no. 21, 205-48

Alesina, A. and Perotti, R. 1997. Fiscal adjustments in OECD countries: composition and macroeconomic effects, IMF Staff Papers, vol. 44, no. 2, 210-48

Angrist, J. D. and Pischke, J. S. 2009. Mostly Harmless Econometrics: An Empiricists Companion, Princeton, Princeton University Press

AMECO. 2018. Annual Macro-Economic database of the European Commission, European Commission, Brussels, available at http://ec.europa.eu/economy_finance/ameco/user/serie/ SelectSerie.cfm [date last accessed: 19 October 2018]

Antonczyk, D., Fitzenberger, B. and Sommerfeld, K. 2010. Rising wage inequality, the decline of collective bargaining, and the gender wage gap, Labour Economics, vol. 17, no. 5, 835-47

Avlijaš, S., Ivanović, N., Vladisavljević, M. and Vujić, S. 2013. Gender Pay Gap in the Western Balkan Countries: Evidence from Serbia, Montenegro and Macedonia, Belgrade, FREN Foundation for the Advancement of Economics.

Barry, U. and Conroy, P. 2014. Ireland in crisis: women, austerity and inequality, pp. 168-207 in Karamessini, M. and Rubery, J. (eds), Women and Austerity. The Economic Crisis and the Future for Gender Equality, Abingdone, UK, Routledge

Bassanini, A., Nunziata, L. and Venn, D. 2009. Job protection legislation and productivity growth in OECD countries, Economic Policy, vol. 2, no. 58, 349-402

Becker, G. S. 1957. The Economics of Discrimination, Chicago, University of Chicago Press

Becker, G. J. 1964. Human Capital: A Theoretical and Empirical Analysis, with Special Reference to Education, Chicago, University of Chicago Press

Bettio, F. and Verashchagina, A. 2014. Women and men in the 'Great European Recession', pp. 57-82 in Karamessini, M. and Rubery, J. (eds), Women and Austerity. The Economic Crisis and the Future for Gender Equality, Abingdone, UK, Routledge

Blau, F. D. and Kahn, L. M. 2000. Gender differences in pay, fournal of Economic Perspectives, vol. 14, no. 4, 75-99

Blinder, A. S. 1973. Wage discrimination: reduced form and structural estimates, fournal of Human Resources, vol. 8, no. 4, 436-55

Bourlès, R., Cette, G., Lopez, J., Mairesse, J. and Nicoletti, G. 2012. 'Do Product Market Regulations in Upstream Sectors Curb Productivity Growth? Panel Data Evidence for OECD 


\section{Austerity and gender inequalities in Europe}

Countries', NBER Working Paper no. 16520, Cambridge, MA, National Bureau of Economic Research

Brandolini, A., Rosolia, A. and Torrini, R. 2010. 'The Distribution of Employees' Labour Earnings in the EU: Data, Concepts and First Results', Eurostat Methodologies and Working Papers, Eurostat

Bryan, M. L. and Jenkins, S. P. 2013. 'Regression Analysis of Country Effects Using Multilevel Data: A Cautionary Tale', IZA Discussion Paper no. 7583, Bonn, IZA

Cameron, A. C. and Trivedi, P. K. 2010. Microeconometrics Using Stata, College Station, Stata Press

Campos, M. M., Depalo, D., Papapetrou, E., Pérez, J. J. and Ramos, R. 2017. Understanding the public sector pay gap, IZA fournal of Labor Policy, vol. 6, no. 7.

Card, D. and Krueger, A. 1994. Minimum wages and employment: a case study of the fast food industry in New Jersey and Pennsylvania, The American Economic Review, vol. 84, 772-84

Considine, J. and Duffy, D. 2016. Keynes and the confidence faeries, Cambridge fournal of Economics, vol. 40, no. 1, 309-25

Crotty, J. 2012. The great Austerity war: what caused the us deficit crisis and who should pay to fix it?, Cambridge fournal of Economics, vol. 36, no. 1, 79-104

De la Rica, S., Dolado, J. J. and Llorens, V. 2008. Ceilings or floors?, Gender wage gaps by education in Spain, fournal of Population Economics, vol. 21, no. 3, 751-76

Devries, P., Guajardo, J., Leigh, D. and Pescatori, A. 2011. 'An Action-Based Analysis of Fiscal Consolidation in OECD Countries', IMF Working Paper no. 11/128

Donald, B., Glasmeier, A., Gray, M. and Lobao, L. 2014. Austerity in the city: economic crisis and urban service decline?, Cambridge fournal of Regions, Economy and Society, vol. 7, no. 1, $3-15$

Escobedoa, A. and Wall, K. 2015. Leave policies in Southern Europe: continuities and changes, Community, Work \& Family, vol. 18, no. 2, 218-35

Eydoux, A. 2014. Women during recessions in France and Germany. The gender biases of public policies, pp. 153-89 in Eydoux, A., Math, A. and Périvier, H. (eds), European Labour Markets, Presses de Sciences-Po, vol. 0(2), pages 7-14, Paris in Times of Crisis. A Gender Perspective, L'Observatoire français des conjonctures économiques

Ferreira, V. 2014. Employment and austerity: changing welfare and gender regimes in Portugal, pp. 207-28 in Karamessini, M. and Rubery, J. (eds), Women and Austerity. The Economic Crisis and the Future for Gender Equality, Abingdone, UK, Routledge

Fulton, L. 2011. 'Widening the Gender Gap: The Impact of Public Sector Pay and Job Cuts on the Employment and Working Conditions of Women in Four Countries', European Federation of Public Service Unions

Galvez-Munoz, L., Rodríguez-Modroño, P. and Addabbo, T. 2014. 'The Impact of Austerity on Women's Work in Italy and Spain', available at http://www.aiel.it/cms/cms-files/submission/ all20140830232109.pdf [date last accessed: 19 October 2018]

Girouard, N. and Price, R. 2004. 'Asset-Price Cycles, "One-off” Factors and Structural Budget Balances', OECD Economics Department Working Paper no. 391

Glasmeier, A. and Lee-Chuvala, C. 2011. Austerity in America: gender and community consequences of restructuring the public sector, Cambridge Fournal of Regions, Economy and Society, vol. 4 , no. 3, 457-74

Gonzales Gago, E. and Segales Kirzner, M. 2014. Women, gender equality and the economic crisis in Spain, pp. 228-48 in Karamessini, M. and Rubery, J. (eds), Women and Austerity. The Economic Crisis and the Future for Gender Equality, Abingdone, UK, Routledge

Gujardo, J., Leigh, D. and Pescatori, A. 2014. Expansionary austerity? International evidence, Fournal of the European Economic Association, vol. 12, no. 4, 949-68

Heckman, J. J. 1979. Sample selection bias as a specification error, Econometrica: fournal of the Econometric Society, vol. 47, no. 1, 153-61

Herndon, T., Ash, M. and Pollin, R. 2014. Does high public debt consistently stifle economic growth? A critique of Reinhart and Rogoff, Cambridge Fournal of Economics, vol. 38, no. 2, 257-79

Jann, B. 2008. The Blinder-Oaxaca decomposition for linear regression models, The Stata fournal, vol. 8, no. 4, 453-79 
Karamessini, M. 2014. Structural crisis and adjustment in Greece: social regression and the challenge to gender equality, pp. 165-86 in Karamessini, M. and Rubery, J. (eds), Women and Austerity. The Economic Crisis and the Future for Gender Equality, Abingdone, UK, Routledge

Karamessini, M. and Rubery, J. 2014. Economic crisis and austerity: challenges to gender equality, pp. 314-52 in Karamessini, M. and Rubery, J. (eds), Women and Austerity. The Economic Crisis and the Future for Gender Equality, Abingdone, UK, Routledge

Kinsella, S. 2012. Is Ireland really the role model for Austerity?, Cambridge fournal of Economics, vol. 36, no. 1, 223-35

Knuth, M. 2014. 'Labour Market Reforms and the "Jobs Miracle" in Germany', European Economic and Social Committee, Workers' Group

Koen, V. and van den Noord, P. 2005. 'Fiscal Gimmickry in Europe: One-off Measures and Creative Accounting', OECD Economic Department Working Paper no. 417

Konzelmann, S. J. 2014. The political economics of austerity, Cambridge fournal of Economics, vol. 38 , no. $4,701-41$

Larch, M. and Salto, M. 2005. Fiscal rules, inertia and discretionary fiscal policy, Applied Economics, vol. 37, no. 10, 1135-46

Lehndorff, S. 2015. Model or liability? The new career of the 'German model', pp. 149-79 in Lehndorff, S. (eds), Divisive Integration. The Triumph of Failed Ideas in Europe-Revisited, Brussels, European Trade Union Institute (ETUI)

Leschke, J., Theodoropoulou, S. and Watt, A. 2015. 'Towards "Europe 2020"? Austerity and New Economic Governance in the EU', pp. 295-330 in Lehndorff, S. (ed.), Divisive Integration. The Triumph of Failed Ideas in Europe-Revisited, Brussels, ETUI

Machin, S. and Puhani, P. 2003. Subject of degree and the gender wage differential: evidence from the UK and Germany, Economics Letters, vol. 79, no. 3, 393-400

Mincer, J. 1958. Investment in human capital and personal income distribution, The fournal of Political Economy, vol. 66, no. 4, 281-302

Molnar, M. 2012. Fiscal consolidation. What factors determine the success of consolidation efforts?, OECD fournal: Economic Studies, vol. 2012, no. 1, 123-49

Mourre, G., Isbasoiu, G. M., Paternister, D. and Salto, M. 2003. 'The Cyclically-Adjusted Budget Balance Used in the EU Fiscal Framework: An Update', Economic Papers no. 478, March 2013, European Commission

Munasinghe, L., Reif, T. and Henriques, A. 2008. Gender gap in wage returns to job tenure and experience, Labour Economics, vol. 15, no. 6, 1296-316

Newell, A. and Reilly, B. 2001. The gender pay gap in the transition from communism: some empirical evidence, Economic Systems, vol. 25, no. 4, 287-304

Oaxaca, R. L. 1973. Male-female wage differentials in urban labor markets, International Economic Review, vol. 14, no. 3, 693-709

OECD. 2018. OECD Economic Outlook. Database Inventory, OECD, Paris, available at http:// www.oecd.org/eco/outlook/Database_Inventory.pdf [date last accessed: 19 October 2018]

Perivier, H. 2018. Recession, austerity and gender. A comparison of eight European labour markets, International Labour Review, Vol 157, no 1, 1-37

Perugini, C. 2017. Employment protection and gender wage gap in Europe, Panoeconomicus, in press (doi: 10.2298/PAN170318025P)

Perugini, C. and Pompei, F. 2017. Temporary jobs, institutions, and wage inequality within education groups in Central-Eastern Europe, World Development, no. 92, 40-59

Perugini, C. and Selezneva, E. 2015. Labour market institutions, crisis and gender earnings gap in Eastern Europe, The Economics of Transition, vol. 23, no. 3, 517-64

Phelps, E. S. 1972. The statistical theory of racism and sexism, American Economic Review, vol. 62, no. 4, 659-61

Reinhart, C. and Rogoff, K. 2009. This Time is Different: Eight Centuries of Financial Folly, Princeton, Princeton University Press

Rodgers, J. R. 2004. Hourly wages of full-time and part-time employees in Australia, Australian Fournal of Labour Economics, vol. 7, 215-38

Romer, C. D. and Romer, D. H. 2010. The macroeconomic effects of tax changes: estimates based on a new measure of fiscal shocks, American Economic Review, vol. 100, no. 3, 763-801

Rubery, J. 2014. From 'women and recession' to 'women and austerity': a framework for analysis, pp. 17-37 in Karamessini, M. and Rubery, J. (eds), Women and Austerity. The Economic Crisis and the Future for Gender Equality, Abingdone, UK, Routledge 
Rubery, J. 2015. Austerity and the future for gender equality in Europe, International Labour Review, vol. 68, no. 4, 715-41

Rubery, J. and Raferty, A. 2014. Gender, recession and austerity in the UK, pp. 123-44 in Karamessini, M. and Rubery, J. (eds), Women and Austerity. The Economic Crisis and the Future for Gender Equality, Abingdone, UK, Routledge

Snijders, T. A. B. and Bosker, R. 1999. Multilevel Analysis: An Introduction to Basic and Advanced Multilevel Modelling, Thousand Oaks, Sage Publications Ltd

Stoiciu, V. 2012. Austerity and Structural Reforms in Romania Severe Measures, Questionable Economic Results and Negative Social Consequences, Berlin, Friedrich-Ebert-Stiftung

Theodoropoulou, S. and Watt, A. 2011. 'Withdrawal Symptoms: An Assessment of the Austerity Packages in Europe', ETUI Working Paper 2011, Brussels, European Trade Union Institute (ETUI)

Tsibouris, G. C., Horton, M. A., Flanagan, M. J. and Maliszewski, W. S. 2006. 'Experience with Large Fiscal Adjustment', IMF Occasional Paper no. 246

Verashchagina, A. and Capparucci, M. 2014. Living through the crisis in Italy: the labour market experiences of men and women, pp. 248-69 in Karamessini, M. and Rubery, J. (eds), Women and Austerity. The Economic Crisis and the Future for Gender Equality, Abingdone, UK, Routledge

Wooldridge, J. M. 2002. Econometric Analysis of Cross Section and Panel Data, Ch. 17, Cambridge, MA, MIT Press 


\section{Appendix}

Table A1. List of variables and abbreviations used in the text and in the tables

\begin{tabular}{|c|c|}
\hline Acronym & Definition \\
\hline lhwage & Log of hourly wage \\
\hline Female & Gender dummy (female $=1$ ) \\
\hline Married & Marital status dummy (married $=1$ ) \\
\hline Age & Number of years \\
\hline Health status & Self-reported health status (from 1 - very good to 5 - very bad) \\
\hline Education & $\begin{array}{l}\text { Highest level of education attained ( } 1 \text { = primary education; } \\
2=\text { secondary education; } 3=\text { tertiary education })\end{array}$ \\
\hline Primary education & Primary education dummy (ISCED levels $0-2=1$ ) \\
\hline Secondary education & Secondary education dummy (ISCED levels $3-4=1$ ) \\
\hline Tertiary education & Tertiary education dummy (ISCED levels $5-6=1$ ) \\
\hline Full time & Full-time/part-time dummy (full time $=1$ ) \\
\hline Second job & Second job dummy (second job $=1$ ) \\
\hline Permanent & Employment status dummy (permanent $=1)$ \\
\hline Firm size & $\begin{array}{l}\text { Size of the employer (coded as } 1 \text { if between } 0 \text { and } 10 \text { employed; } 2 \\
\text { between } 11 \text { and } 49 ; 3 \text { if over } 50 \text { ) }\end{array}$ \\
\hline Firm size $(0-10)$ & Small firm size dummy (between 0 and 10 employed $=1$ ) \\
\hline Firm size $(11-49)$ & Medium firm size dummy (between 11 and 49 employed $=1$ ) \\
\hline Firm size (over 50) & Large firm size dummy (over 50 employed $=1$ ) \\
\hline Urban & Place of residence dummy (urban $=1)$ \\
\hline Occupation & $\begin{array}{l}\text { Type of occupation (ISCO-08 classification): 1. Managers, } \\
\text { 2. Professionals, 3. Technicians and Associate Professionals, } \\
\text { 4. Clerical Support Workers, 5. Services and Sales } \\
\text { Workers, 6. Skilled Agricultural, Forestry and Fishery Workers, } \\
\text { 7. Craft and Related Trade Workers, 8. Plant and Machine } \\
\text { Operators and Assemblers, 9. Elementary Occupations }\end{array}$ \\
\hline Sector & $\begin{array}{l}\text { Sector of employment (NACE sections): 1. Agriculture (section } \\
\text { A), 2. Industry (B-E), 3. Construction (F), 4. Trade (G), } \\
\text { 5. Transport (H), 6. Hotels and Restaurants (I), 7. Information } \\
\text { and Communications (J), 8. Financial and Insurance Activities (K), } \\
\text { 9. Real Estate, Professional and Administrative Activities (L-N), } \\
\text { 10. Public Administration (O), 11. Education (P), 12. Health and } \\
\text { Social Work Activities (Q), 13. Other services (R-U) }\end{array}$ \\
\hline IMR & Inverse mill ratio (sample selection coefficient) \\
\hline CAPB & Cyclically adjusted primary balance \\
\hline GWG & $\begin{array}{l}\text { Gender wage gap (not adjusted for the labour market characteristics } \\
\text { of men and women) }\end{array}$ \\
\hline AGWG & $\begin{array}{l}\text { Adjusted gender wage gap (adjusted for the labour market } \\
\text { characteristics of men and women) }\end{array}$ \\
\hline TG, CG & $\begin{array}{l}\text { In the differences-in-differences model: treatment group, control } \\
\text { group }\end{array}$ \\
\hline $\mathrm{T}_{2010}, \mathrm{~T}_{2013}$ & $\begin{array}{l}\text { In the differences-in-differences model: } T_{2010}=\text { initial year; } \\
T_{2013}=\text { final year }\end{array}$ \\
\hline AUS & $\begin{array}{l}\text { Country-level continuous variable describing austerity measures } \\
\text { (expressed as CAPB changes) }\end{array}$ \\
\hline AUS_L1 & Country-level CAPB change lagged one year \\
\hline AUS_L2 & Country-level CAPB change lagged two years \\
\hline AUS_L3 & Country-level CAPB change lagged three years \\
\hline AUS_d & $\begin{array}{l}\text { Country-level dummy variable describing austerity measures } \\
\text { (coded }=1 \text { if the CAPB change exceeded } 0.5 \% \text { and } 0 \text { otherwise) }\end{array}$ \\
\hline
\end{tabular}


Table A1. (Continued)

\begin{tabular}{|c|c|}
\hline Acronym & Definition \\
\hline$\overline{\text { AUS_d_L1 }}$ & $\begin{array}{l}\text { Country-level dummy variable describing austerity measures } \\
\text { (coded }=1 \text { if the CAPB change exceeded } 0.5 \% \text { and } 0 \text { otherwise), } \\
\text { lagged one year }\end{array}$ \\
\hline AUS_d_L2 & $\begin{array}{l}\text { Country-level dummy variable describing austerity measures } \\
\text { (coded }=1 \text { if the CAPB change exceeded } 0.5 \% \text { and } 0 \text { otherwise), } \\
\text { lagged two years }\end{array}$ \\
\hline AUS_d_L3 & $\begin{array}{l}\text { Country-level dummy variable describing austerity measures } \\
\text { (coded }=1 \text { if the CAPB change exceeded } 0.5 \% \text { and } 0 \text { otherwise), } \\
\text { lagged three years }\end{array}$ \\
\hline $\begin{array}{l}\text { TB_AUS_d } \\
\text { (same for L1, L2, } \\
\text { L3) }\end{array}$ & $\begin{array}{l}\text { For AUS_d = } 1 \text {, country-level dummy variable identifying austerity } \\
\text { measures that were predominantly tax- (increase) based [code as } \\
1 \text { if the change in the cyclically adjusted structural revenue (as a } \\
\% \text { of GDP) was higher than the change in the cyclically adjusted } \\
\text { structural expenditure; coded as } 0 \text { otherwise] }\end{array}$ \\
\hline $\begin{array}{l}\text { EX_AUS_d } \\
\text { (same for L1, L2, } \\
\text { L3) }\end{array}$ & $\begin{array}{l}\text { For AUS_d }=1 \text {, country-level dummy variable identifying austerity } \\
\text { measures that were predominantly expenditure- (cuts) based (coded } \\
\text { as } 1 \text { when TB_AUS_d }=0 \text { and as } 0 \text { when TB_AUS_d }=1 \text { ) }\end{array}$ \\
\hline AUS_p_3_L1 & $\begin{array}{l}\text { Country-level continuous variable describing } 3 \text { years' austerity plans } \\
\text { (obtained as the sum of the CAPB change in years } t-1, t-2 \text { and } t-3 \text { ) }\end{array}$ \\
\hline AUS_p_2_L1 & $\begin{array}{l}\text { Country-level continuous variable describing } 3 \text { years' austerity plans } \\
\text { (obtained as the sum of the CAPB change in years } t-1 \text { and } t-2 \text { ) }\end{array}$ \\
\hline AUS_p_3_d_L1 & $\begin{array}{l}\text { Country-level dummy variable describing } 2 \text { years' austerity plans } \\
\text { (coded as } 1 \text { if the sum of the CAPB change in years } t-1, t-2 \text { and } t-3 \\
\text { exceeds } 1 \% ; 0 \text { otherwise) }\end{array}$ \\
\hline AUS_p_2_d_L1 & $\begin{array}{l}\text { Country-level dummy variable describing } 2 \text { years' austerity plans } \\
\text { (coded as } 1 \text { if the sum of the CAPB change in years } t-1 \text { and } t-2 \\
\text { exceeds } 1 \% ; 0 \text { otherwise) }\end{array}$ \\
\hline $\begin{array}{l}\text { TB } \\
\text { AUS_p_3_d_L1 } \\
\text { EB AUS } p 3 d \text { L } 1\end{array}$ & $\begin{array}{l}\text { For AUS_p_3_d_L } 1=1 \text {, country-level dummy variable(s) describing } \\
3 \text { years' austerity plans predominantly tax-based or expenditure- } \\
\text { (cuts) based }\end{array}$ \\
\hline $\begin{array}{l}\text { AUS_p_2_d_L1 } \\
\text { EB AUS_p_2_d L1 }\end{array}$ & $\begin{array}{l}\text { For AUS_p_3_d_L } 1=1 \text {, country-level dummy variable(s) describing } \\
2 \text { years' austerity plans predominantly tax-based or expenditure- } \\
\text { (cuts) based }\end{array}$ \\
\hline
\end{tabular}




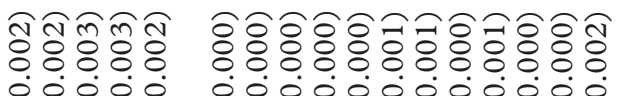

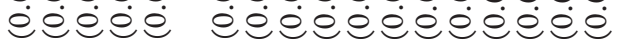

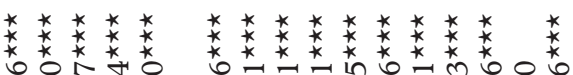

$\stackrel{n}{\stackrel{n}{0}}$

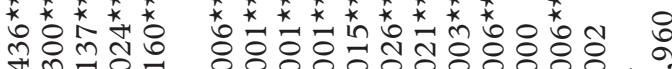
iño:

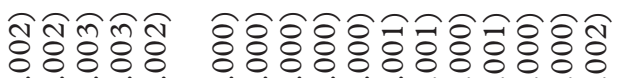

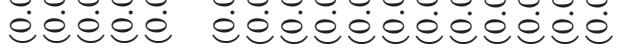

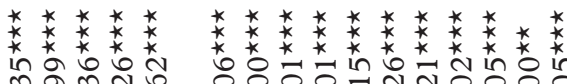

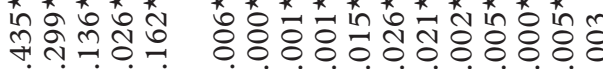

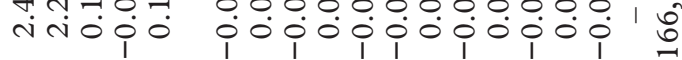

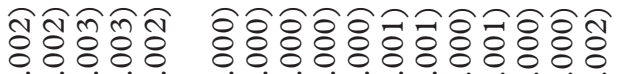

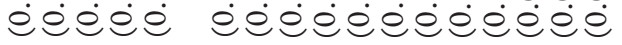

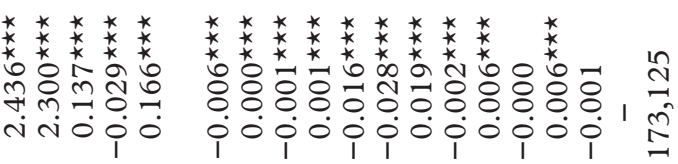

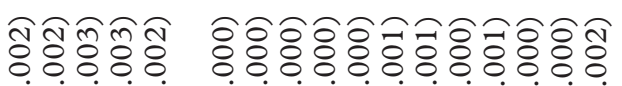

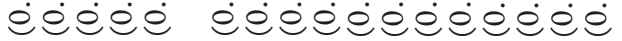

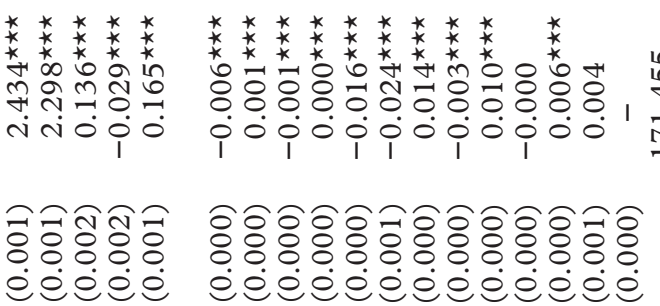

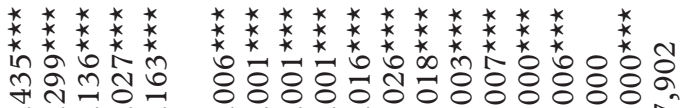
niñó

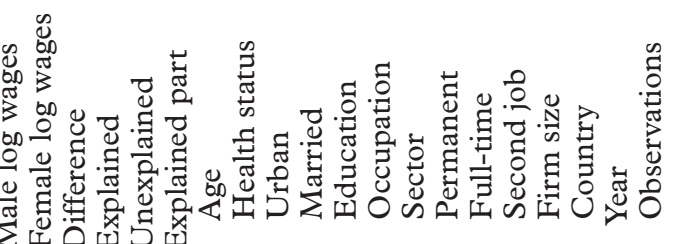


Table A3. Adjusted gender wage gap in EU-28 countries, 2010-13

\begin{tabular}{|c|c|c|c|c|c|c|}
\hline & Country & Observations & 2010 & 2011 & 2012 & 2013 \\
\hline AT & Austria & 17,827 & 0.144 & 0.14 & 0.149 & 0.131 \\
\hline $\mathrm{BE}$ & Belgium & 17,823 & 0.102 & 0.092 & 0.096 & 0.101 \\
\hline BG & Bulgaria & 17,896 & 0.183 & 0.202 & 0.173 & 0.167 \\
\hline CY & Cyprus & 16,168 & 0.260 & 0.249 & 0.213 & 0.184 \\
\hline $\mathrm{CZ}$ & Czech Republic & 26,381 & 0.242 & 0.242 & 0.243 & 0.239 \\
\hline $\mathrm{DE}$ & Germany & 39,421 & 0.13 & 0.158 & 0.143 & 0.145 \\
\hline $\mathrm{DK}$ & Denmark & 19,947 & 0.139 & 0.132 & 0.145 & 0.144 \\
\hline $\mathrm{EE}$ & Estonia & 18,625 & 0.278 & 0.31 & 0.327 & 0.313 \\
\hline EL & Greece & 11,434 & 0.142 & 0.099 & 0.088 & 0.057 \\
\hline ES & Spain & 32,202 & 0.140 & 0.138 & 0.153 & 0.115 \\
\hline FI & Finland & 29,865 & 0.150 & 0.159 & 0.148 & 0.129 \\
\hline FR & France & 35,742 & 0.086 & 0.106 & 0.075 & 0.108 \\
\hline HR & Croatia & 14,235 & 0.143 & 0.147 & 0.142 & 0.153 \\
\hline HU & Hungary & 33,236 & 0.141 & 0.147 & 0.134 & 0.126 \\
\hline IE & Ireland & 11,818 & 0.100 & 0.085 & 0.099 & 0.112 \\
\hline IT & Italy & 47,893 & 0.112 & 0.098 & 0.086 & 0.103 \\
\hline LT & Lithuania & 15,860 & 0.136 & 0.172 & 0.185 & 0.193 \\
\hline LU & Luxembourg & 18,335 & 0.091 & 0.078 & 0.060 & 0.069 \\
\hline LV & Latvia & 17,923 & 0.203 & 0.176 & 0.198 & 0.206 \\
\hline MT & Malta & 13,692 & 0.091 & 0.092 & 0.084 & 0.123 \\
\hline NL & Netherlands & 37,079 & 0.129 & 0.134 & 0.130 & 0.134 \\
\hline PL & Poland & 37,672 & 0.136 & 0.136 & 0.142 & 0.137 \\
\hline PT & Portugal & 17,811 & 0.154 & 0.16 & 0.150 & 0.173 \\
\hline RO & Romania & 18,488 & 0.129 & 0.116 & 0.105 & 0.095 \\
\hline SE & Sweden & 23,609 & 0.163 & 0.166 & 0.181 & 0.163 \\
\hline SI & Slovenia & 35,828 & 0.158 & 0.170 & 0.173 & 0.143 \\
\hline SK & Slovakia & 22,695 & 0.193 & 0.186 & 0.185 & 0.197 \\
\hline \multirow[t]{2}{*}{ UK } & United Kingdom & 17,827 & 0.147 & 0.109 & 0.116 & 0.128 \\
\hline & All & 677,702 & 0.165 & 0.166 & 0.162 & 0.160 \\
\hline
\end{tabular}

Note: Our elaboration of EU-SILC data; all coefficients significant at $1 \%$ level. 
Table A4. Austerity in EU-28 (yearly CAPB change), 2007-13

\begin{tabular}{|c|c|c|c|c|c|c|c|c|}
\hline Country & & 2007 & 2008 & 2009 & 2010 & 2011 & 2012 & 2013 \\
\hline AT & Austria & 0.23 & -0.37 & -0.27 & -0.19 & 0.70 & 0.60 & 0.50 \\
\hline $\mathrm{BE}$ & Belgium & -0.77 & -0.60 & -2.09 & -0.02 & -0.20 & 0.60 & 0.40 \\
\hline BG & Bulgaria & -1.70 & 0.00 & -3.80 & 1.00 & 0.70 & 1.80 & -0.30 \\
\hline $\mathrm{CY}$ & Cyprus & 3.30 & -2.70 & -4.30 & 0.60 & -0.10 & 1.20 & 3.90 \\
\hline $\mathrm{CZ}$ & Czech Republic & 0.73 & -0.39 & -0.99 & 1.19 & 1.50 & 1.30 & 1.40 \\
\hline $\mathrm{DE}$ & Germany & 0.67 & 0.04 & 0.37 & -1.67 & 0.70 & 0.70 & 0.10 \\
\hline DK & Denmark & 0.48 & -0.24 & -2.22 & -0.65 & 0.30 & 0.20 & -0.30 \\
\hline $\mathrm{EE}$ & Estonia & -1.07 & -0.33 & 3.21 & 0.83 & 0.10 & -0.50 & -0.20 \\
\hline EL & Greece & -0.96 & -1.40 & -2.21 & 6.20 & 5.20 & 3.90 & 0.80 \\
\hline ES & Spain & 0.02 & -5.19 & -3.77 & 1.37 & 1.20 & 3.60 & 1.70 \\
\hline FI & Finland & -0.41 & -0.47 & -1.48 & -1.66 & 0.20 & -0.20 & -0.30 \\
\hline FR & France & -0.53 & 0.60 & -2.07 & -0.09 & 1.00 & 0.80 & 0.30 \\
\hline HR & Croatia & -0.40 & -0.40 & 0.90 & 0.40 & -1.30 & 3.70 & 0.60 \\
\hline $\mathrm{HU}$ & Hungary & 5.82 & 1.49 & 2.41 & -1.59 & -0.90 & 3.40 & -0.10 \\
\hline IE & Ireland & -3.48 & -4.12 & -0.89 & 0.97 & 1.90 & 1.90 & 2.30 \\
\hline IT & Italy & 1.20 & -0.46 & -0.71 & -0.17 & 0.30 & 2.70 & -0.10 \\
\hline LT & Lithuania & -2.30 & -1.00 & 1.30 & 2.20 & -0.30 & 1.20 & 0.10 \\
\hline LU & Luxembourg & -0.19 & 0.93 & -0.44 & -1.80 & 1.20 & 1.20 & -0.40 \\
\hline LV & Latvia & -0.90 & -0.30 & 1.30 & 2.90 & 0.90 & 1.10 & -1.10 \\
\hline MT & Malta & -0.50 & -2.40 & 2.70 & -1.70 & 1.40 & -0.90 & 0.70 \\
\hline NL & Netherlands & -1.08 & 0.20 & -1.80 & -0.84 & 0.00 & 1.20 & 1.10 \\
\hline PL & Poland & -0.23 & -1.25 & -2.64 & -0.39 & 2.20 & 2.20 & 0.40 \\
\hline PT & Portugal & 0.52 & -0.66 & -4.14 & 0.18 & 3.20 & 3.80 & 0.40 \\
\hline RO & Romania & -0.70 & -3.30 & 0.00 & 3.20 & 2.60 & 0.70 & 1.50 \\
\hline SE & Sweden & 0.68 & -0.05 & 0.72 & -1.95 & -0.60 & -0.10 & -0.30 \\
\hline SI & Slovenia & -0.32 & -1.18 & 0.02 & 0.59 & 0.00 & 2.80 & 0.50 \\
\hline SK & Slovakia & -0.20 & -0.60 & -1.70 & -0.20 & 3.20 & 0.70 & 2.00 \\
\hline UK & United Kingdom & -0.52 & -0.27 & -2.39 & 1.28 & 1.70 & -0.90 & 1.90 \\
\hline
\end{tabular}

Sources: AMECO database (2010 onwards) and our elaboration of AMECO database and OECD (2018) for 2007-09. Each column reports the CAPB change with respect to the previous year. 
Table A5. Adjusted gender wage gap change in the control (CG) and treatment (TG) groups

\begin{tabular}{|c|c|c|c|c|c|c|}
\hline & \multicolumn{2}{|l|}{ (1) } & \multicolumn{2}{|l|}{ (2) } & \multicolumn{2}{|l|}{ (3) } \\
\hline & CG & TG & CG & TG & CG & TG \\
\hline Female & $\begin{array}{l}-0.140^{\star \star \star} \\
(0.016)\end{array}$ & $\begin{array}{l}-0.151^{\star \star \star} \\
(0.018)\end{array}$ & $\begin{array}{l}-0.141^{\star \star \star} \\
(0.017)\end{array}$ & $\begin{array}{l}-0.151^{\star \star \star} \\
(0.018)\end{array}$ & $\begin{array}{l}-0.140^{\star \star \star} \\
(0.016)\end{array}$ & $\begin{array}{l}-0.150^{\star \star \star} \\
(0.016)\end{array}$ \\
\hline Female_2013 & $\begin{array}{c}-0.004 \\
(0.021)\end{array}$ & $\begin{array}{l}-0.048^{\star \star} \\
(0.024)\end{array}$ & $\begin{array}{c}-0.003 \\
(0.022)\end{array}$ & $\begin{array}{c}-0.048^{\star \star} \\
(0.024)\end{array}$ & $\begin{array}{c}-0.004 \\
(0.021)\end{array}$ & $\begin{array}{l}-0.057^{\star \star \star} \\
(0.021)\end{array}$ \\
\hline Married & $\begin{array}{c}0.016 \\
(0.012)\end{array}$ & $\begin{array}{l}0.053^{\star \star \star} \\
(0.014)\end{array}$ & $\begin{array}{c}0.015 \\
(0.014)\end{array}$ & $\begin{array}{l}0.053^{\star \star \star} \\
(0.014)\end{array}$ & $\begin{array}{c}0.016 \\
(0.012)\end{array}$ & $\begin{array}{l}0.027^{\star \star} \\
(0.012)\end{array}$ \\
\hline Age & $\begin{array}{l}0.315^{\star \star \star} \\
(0.065)\end{array}$ & $\begin{array}{l}0.287^{\star \star \star} \\
(0.090)\end{array}$ & $\begin{array}{l}0.280^{\star \star \star} \\
(0.069)\end{array}$ & $\begin{array}{l}0.287^{\star \star \star} \\
(0.090)\end{array}$ & $\begin{array}{l}0.315^{\star \star \star} \\
(0.065)\end{array}$ & $\begin{array}{l}0.300^{\star \star \star} \\
(0.083)\end{array}$ \\
\hline $\mathrm{Age}^{2}$ & $\begin{array}{l}-0.024^{\star \star \star} \\
(0.007)\end{array}$ & $\begin{array}{l}-0.024^{\star \star} \\
(0.010)\end{array}$ & $\begin{array}{l}-0.021^{\star \star \star} \\
(0.008)\end{array}$ & $\begin{array}{l}-0.024^{\star \star} \\
(0.010)\end{array}$ & $\begin{array}{l}-0.024^{\star \star \star} \\
(0.007)\end{array}$ & $\begin{array}{l}-0.024^{\star \star} \\
(0.009)\end{array}$ \\
\hline Health status & $\begin{array}{l}-0.018^{\star \star} \\
(0.008)\end{array}$ & $\begin{array}{l}-0.033^{\star \star \star} \\
(0.009)\end{array}$ & $\begin{array}{l}-0.020^{\star \star} \\
(0.009)\end{array}$ & $\begin{array}{l}-0.033^{\star \star \star} \\
(0.009)\end{array}$ & $\begin{array}{l}-0.018^{\star \star} \\
(0.008)\end{array}$ & $\begin{array}{l}-0.050^{\star \star \star} \\
(0.008)\end{array}$ \\
\hline $\begin{array}{l}\text { Secondary } \\
\text { education }\end{array}$ & 0.034 & $0.108^{\star \star \star}$ & 0.024 & $0.108^{\star \star \star}$ & 0.034 & $0.121^{\star \star \star}$ \\
\hline & $(0.029)$ & $(0.030)$ & $(0.033)$ & $(0.030)$ & $(0.029)$ & $(0.024)$ \\
\hline $\begin{array}{l}\text { Tertiary } \\
\text { education }\end{array}$ & $0.089^{\star \star \star}$ & $0.195^{\star \star \star}$ & $0.070^{\star}$ & $0.195^{\star \star \star}$ & $0.089^{\star \star \star}$ & $0.193^{\star \star \star}$ \\
\hline & $(0.032)$ & $(0.033)$ & $(0.036)$ & $(0.033)$ & $(0.032)$ & $(0.028)$ \\
\hline Permanent & $\begin{array}{l}0.412^{\star \star \star} \\
(0.021)\end{array}$ & $\begin{array}{l}0.515^{\star \star \star} \\
(0.026)\end{array}$ & $\begin{array}{l}0.415^{\star \star \star} \\
(0.021)\end{array}$ & $\begin{array}{l}0.515^{\star \star \star} \\
(0.026)\end{array}$ & $\begin{array}{l}0.412^{\star \star \star} \\
(0.021)\end{array}$ & $\begin{array}{l}0.481^{\star \star \star} \\
(0.023)\end{array}$ \\
\hline Urban & $\begin{array}{c}0.021^{\star} \\
(0.011)\end{array}$ & $\begin{array}{l}0.120^{\star \star \star} \\
(0.013)\end{array}$ & $\begin{array}{c}0.022^{\star} \\
(0.012)\end{array}$ & $\begin{array}{l}0.120^{\star \star \star} \\
(0.013)\end{array}$ & $\begin{array}{c}0.021^{\star} \\
(0.011)\end{array}$ & $\begin{array}{l}0.104^{\star \star \star} \\
(0.011)\end{array}$ \\
\hline Constant & $\begin{array}{l}1.563^{\star \star \star} \\
(0.144)\end{array}$ & $\begin{array}{l}1.348^{\star \star \star} \\
(0.226)\end{array}$ & $\begin{array}{l}1.652^{\star \star \star} \\
(0.154)\end{array}$ & $\begin{array}{l}1.348^{\star \star \star} \\
(0.226)\end{array}$ & $\begin{array}{l}1.563^{\star \star \star} \\
(0.144)\end{array}$ & $\begin{array}{l}1.347^{\star \star \star} \\
(0.205)\end{array}$ \\
\hline Observations & 11,891 & 6,636 & 10,799 & 6,636 & 11,891 & 8,407 \\
\hline Adjusted $R^{2}$ & 0.488 & 0.430 & 0.476 & 0.430 & 0.488 & 0.439 \\
\hline
\end{tabular}

Notes: All estimations include country, year, country ${ }^{\star}$ year and occupation dummies; sample selection correction. Clustered SEs in parenthesis. See Table A1 for the variable and acronym descriptions. Columns: (1) treatment group: CZ, IE, ES, EL; control group: BE, DK, FI, SE, PL. (2) treatment group: CZ, IE, ES, EL; control group: DK, FI, SE, PL. (3) treatment group CZ, IE, ES, EL, PT; control group: BE, DK, FI, SE, PL.

Significance at the ${ }^{\star} 10 \%, \star \star 5 \%, \star \star \star 1 \%$ level. 
Table A6. Tax-based and expenditure-based austerity and gender wage gap (yearly and cumulative $C A P B$ changes as a dummy variable), country fixed-effect estimation

\begin{tabular}{|c|c|c|c|c|c|}
\hline & (1) & $(2)$ & (3) & (4) & (5) \\
\hline Female & $\begin{array}{l}-0.159^{\star \star \star} \\
(0.001)\end{array}$ & $\begin{array}{l}-0.158^{\star \star \star} \\
(0.001)\end{array}$ & $\begin{array}{l}-0.162^{\star \star \star} \\
(0.001)\end{array}$ & $\begin{array}{l}-0.159^{\star \star \star} \\
(0.001)\end{array}$ & $\begin{array}{l}-0.156^{\star \star \star} \\
(0.001)\end{array}$ \\
\hline Female`EB_AUS_d_L1 & $\begin{array}{l}-0.007^{\star \star \star} \\
(0.003)\end{array}$ & & & & \\
\hline Female ${ }^{\star}$ TB_AUS_d_L1 & $\begin{array}{l}-0.009^{\star \star \star} \\
(0.002)\end{array}$ & & & & \\
\hline Female ${ }^{\star} E B$ AUS_d_L2 & & $\begin{array}{l}-0.021^{\star \star \star} \\
(0.003)\end{array}$ & & & \\
\hline Female*TB_AUS_d_L2 & & $\begin{array}{l}-0.017^{\star \star \star} \\
(0.003)\end{array}$ & & & \\
\hline Female`EB_AUS_d_L3 & & & $\begin{array}{l}-0.022^{\star \star \star} \\
(0.003)\end{array}$ & & \\
\hline Female ${ }^{\star}$ TB_AUS_d_L3 & & & $\begin{array}{c}0.003 \\
(0.003)\end{array}$ & & \\
\hline Female EB_AUS_p_2_d_L1 & & & & $\begin{array}{l}-0.016^{\star \star \star} \\
(0.003)\end{array}$ & \\
\hline Female $^{\star}$ TB_AUS_p_2_d_L1 & & & & $\begin{array}{l}-0.012^{\star \star \star} \\
(0.002)\end{array}$ & \\
\hline Female EB_AUS_p_3_d_L1 & & & & & $\begin{array}{l}-0.026^{\star \star \star} \\
(0.004)\end{array}$ \\
\hline Female*TB_AUS_p_3_d_L1 & & & & & $\begin{array}{l}-0.027^{\star \star \star} \\
(0.002)\end{array}$ \\
\hline Married & $\begin{array}{l}0.030^{\star \star \star} \\
(0.001)\end{array}$ & $\begin{array}{l}0.030^{\star \star \star} \\
(0.001)\end{array}$ & $\begin{array}{l}0.030^{\star \star \star} \\
(0.001)\end{array}$ & $\begin{array}{l}0.030^{\star \star \star} \\
(0.001)\end{array}$ & $\begin{array}{l}0.029^{\star \star \star} \\
(0.001)\end{array}$ \\
\hline Age & $\begin{array}{l}0.224^{\star \star \star} \\
(0.006)\end{array}$ & $\begin{array}{l}0.224^{\star \star \star} \\
(0.006)\end{array}$ & $\begin{array}{l}0.223^{\star \star \star} \\
(0.006)\end{array}$ & $\begin{array}{l}0.224^{\star \star \star} \\
(0.006)\end{array}$ & $\begin{array}{l}0.224^{\star \star \star} \\
(0.006)\end{array}$ \\
\hline $\mathrm{Age}^{2}$ & $\begin{array}{l}-0.018^{\star \star \star} \\
(0.001)\end{array}$ & $\begin{array}{l}-0.018^{\star \star \star} \\
(0.001)\end{array}$ & $\begin{array}{l}-0.018^{\star \star \star} \\
(0.001)\end{array}$ & $\begin{array}{l}-0.018^{\star \star \star} \\
(0.001)\end{array}$ & $\begin{array}{l}-0.018^{\star \star \star} \\
(0.001)\end{array}$ \\
\hline Health status & $\begin{array}{l}-0.015^{\star \star \star} \\
(0.001)\end{array}$ & $\begin{array}{l}-0.015^{\star \star \star} \\
(0.001)\end{array}$ & $\begin{array}{l}-0.015^{\star \star \star} \\
(0.001)\end{array}$ & $\begin{array}{l}-0.015^{\star \star \star} \\
(0.001)\end{array}$ & $\begin{array}{l}-0.015^{\star \star \star} \\
(0.001)\end{array}$ \\
\hline Secondary education & $\begin{array}{l}0.083^{\star \star \star} \\
(0.002)\end{array}$ & $\begin{array}{l}0.083^{\star \star \star} \\
(0.002)\end{array}$ & $\begin{array}{l}0.083^{\star \star \star} \\
(0.002)\end{array}$ & $\begin{array}{l}0.083^{\star \star \star} \\
(0.002)\end{array}$ & $\begin{array}{l}0.083^{\star \star \star} \\
(0.002)\end{array}$ \\
\hline Tertiary education & $\begin{array}{l}0.216^{\star \star \star} \\
(0.002)\end{array}$ & $\begin{array}{l}0.216^{\star \star \star} \\
(0.002)\end{array}$ & $\begin{array}{l}0.216^{\star \star \star} \\
(0.002)\end{array}$ & $\begin{array}{l}0.216^{\star \star \star} \\
(0.002)\end{array}$ & $\begin{array}{l}0.216^{\star \star \star} \\
(0.002)\end{array}$ \\
\hline Full time & $\begin{array}{l}-0.036^{\star \star \star} \\
(0.002)\end{array}$ & $\begin{array}{l}-0.036^{\star \star \star} \\
(0.002)\end{array}$ & $\begin{array}{l}-0.036^{\star \star \star} \\
(0.002)\end{array}$ & $\begin{array}{l}-0.036^{\star \star \star} \\
(0.002)\end{array}$ & $\begin{array}{l}-0.035^{\star \star \star} \\
(0.002)\end{array}$ \\
\hline Second job & $\begin{array}{l}-0.028^{\star \star \star} \\
(0.010)\end{array}$ & $\begin{array}{l}-0.028^{\star \star \star} \\
(0.010)\end{array}$ & $\begin{array}{l}-0.028^{\star \star \star} \\
(0.010)\end{array}$ & $\begin{array}{l}-0.028^{\star \star \star} \\
(0.010)\end{array}$ & $\begin{array}{l}-0.028^{\star \star \star} \\
(0.010)\end{array}$ \\
\hline Permanent & $\begin{array}{l}0.115^{\star \star \star} \\
(0.002)\end{array}$ & $\begin{array}{l}0.115^{\star \star \star} \\
(0.002)\end{array}$ & $\begin{array}{l}0.115^{\star \star \star} \\
(0.002)\end{array}$ & $\begin{array}{l}0.115^{\star \star \star} \\
(0.002)\end{array}$ & $\begin{array}{l}0.115^{\star \star \star} \\
(0.002)\end{array}$ \\
\hline Firm size (11-49) & $\begin{array}{l}0.064^{\star \star \star} \\
(0.001)\end{array}$ & $\begin{array}{l}0.064^{\star \star \star} \\
(0.001)\end{array}$ & $\begin{array}{l}0.064^{\star \star \star} \\
(0.001)\end{array}$ & $\begin{array}{l}0.064^{\star \star \star} \\
(0.001)\end{array}$ & $\begin{array}{l}0.064^{\star \star \star} \\
(0.001)\end{array}$ \\
\hline Firm size (over 50) & $\begin{array}{l}0.151^{\star \star \star} \\
(0.001)\end{array}$ & $\begin{array}{l}0.151^{\star \star \star} \\
(0.001)\end{array}$ & $\begin{array}{l}0.151^{\star \star \star} \\
(0.001)\end{array}$ & $\begin{array}{l}0.151^{\star \star \star} \\
(0.001)\end{array}$ & $\begin{array}{l}0.151^{\star \star \star} \\
(0.001)\end{array}$ \\
\hline Urban & $\begin{array}{l}0.037^{\star \star \star} \\
(0.001)\end{array}$ & $\begin{array}{l}0.037^{\star \star \star} \\
(0.001)\end{array}$ & $\begin{array}{l}0.037^{\star \star \star} \\
(0.001)\end{array}$ & $\begin{array}{l}0.037^{\star \star \star} \\
(0.001)\end{array}$ & $\begin{array}{l}0.037^{\star \star \star} \\
(0.001)\end{array}$ \\
\hline Constant & $\begin{array}{l}1.923^{\star \star \star} \\
(0.017)\end{array}$ & $\begin{array}{l}1.921^{\star \star \star} \\
(0.017)\end{array}$ & $\begin{array}{l}1.924^{\star \star \star} \\
(0.017)\end{array}$ & $\begin{array}{l}1.921^{\star \star \star} \\
(0.017)\end{array}$ & $\begin{array}{l}1.920^{\star \star \star} \\
(0.017)\end{array}$ \\
\hline $\begin{array}{l}\text { Test }(\mathrm{F}) \\
\quad \text { EB_AUS }=\text { TB_AUS }\end{array}$ & 0.59 & 1.11 & $31.55^{\star \star \star}$ & 1.39 & 0.03 \\
\hline Observations & 677,702 & 677,702 & 677,702 & 677,702 & 677,702 \\
\hline Adjusted $R^{2}$ & 0.696 & 0.696 & 0.696 & 0.696 & 0.696 \\
\hline
\end{tabular}

Notes: All estimations include sector, occupation and country/year dummies; sample selection correction. Clustered SEs in parenthesis. See Table A1 for variable and acronym descriptions.

Significance at the ${ }^{\star} 10 \%, \star \star 5 \%, \star \star \star 1 \%$ level. 
Table A7. Austerity plans and sectorial gender segregation (no job variables), country fixed-effect estimation

\begin{tabular}{|c|c|c|c|c|}
\hline $\begin{array}{l}\text { Dependent variable: sectors } \\
\text { ordered by increasing average wage }\end{array}$ & (1) & (2) & (3) & $(4)$ \\
\hline Female & $-0.050^{\star \star \star}$ & $-0.043^{\star \star \star}$ & $-0.050^{\star \star \star}$ & $-0.043^{\star \star \star}$ \\
\hline Female^AUS_p_2_d_L1 & $\begin{array}{l}(0.005) \\
-0.067^{\star \star \star}\end{array}$ & & & \\
\hline Female^AUS_p_3_d_L1 & & $\begin{array}{l}-0.103^{\star \star \star} \\
(0.010)\end{array}$ & & \\
\hline Female`EB_AUS_p_2_d_L1 & & & $\begin{array}{c}-0.104^{\star \star \star} \\
(0.014)\end{array}$ & \\
\hline Female`TB_AUS_p_2_d_L1 & & & $\begin{array}{l}-0.045^{\star \star \star} \\
(0.011)\end{array}$ & \\
\hline Female`EB_AUS_p_3_d_L1 & & & & $\begin{array}{c}-0.080^{\star \star \star} \\
(0.018)\end{array}$ \\
\hline Female`TB_AUS_p_3_d_L1 & & & & $\begin{array}{l}-0.110^{\star \star \star} \\
(0.011)\end{array}$ \\
\hline Married & $\begin{array}{l}0.043^{\star \star \star \star} \\
(0.005)\end{array}$ & $\begin{array}{l}0.043^{\star \star \star \star} \\
(0.005)\end{array}$ & $\begin{array}{l}0.043^{\star \star \star} \\
(0.005)\end{array}$ & $\begin{array}{l}0.043^{\star \star \star} \\
(0.005)\end{array}$ \\
\hline Age & $\begin{array}{l}0.630^{\star \star \star} \\
(0.027)\end{array}$ & $\begin{array}{l}0.629^{\star \star \star} \\
(0.027)\end{array}$ & $\begin{array}{l}0.630^{\star \star \star} \\
(0.027)\end{array}$ & $\begin{array}{l}0.629^{\star \star \star} \\
(0.027)\end{array}$ \\
\hline $\mathrm{Age}^{2}$ & $\begin{array}{l}-0.056^{\star \star \star} \\
(0.003)\end{array}$ & $\begin{array}{l}-0.056^{\star \star \star} \\
(0.003)\end{array}$ & $\begin{array}{l}-0.056^{\star \star \star} \\
(0.003)\end{array}$ & $\begin{array}{l}-0.056^{\star \star \star} \\
(0.003)\end{array}$ \\
\hline Health status & $\begin{array}{l}-0.044^{\star \star \star} \\
(0.003)\end{array}$ & $\begin{array}{l}-0.044^{\star \star \star} \\
(0.003)\end{array}$ & $\begin{array}{l}-0.044^{\star \star \star} \\
(0.003)\end{array}$ & $\begin{array}{l}-0.044^{\star \star \star} \\
(0.003)\end{array}$ \\
\hline Secondary education & $\begin{array}{l}0.433^{\star \star \star} \\
(0.007)\end{array}$ & $\begin{array}{l}0.433^{\star \star \star} \\
(0.007)\end{array}$ & $\begin{array}{l}0.433^{\star \star \star} \\
(0.007)\end{array}$ & $\begin{array}{l}0.433^{\star \star \star} \\
(0.007)\end{array}$ \\
\hline Tertiary education & $\begin{array}{l}1.390^{\star \star \star} \\
(0.009)\end{array}$ & $\begin{array}{l}1.390^{\star \star \star} \\
(0.009)\end{array}$ & $\begin{array}{l}1.390^{\star \star \star} \\
(0.009)\end{array}$ & $\begin{array}{l}1.390^{\star \star \star} \\
(0.009)\end{array}$ \\
\hline Urban & $\begin{array}{l}0.049^{\star \star \star} \\
(0.005)\end{array}$ & $\begin{array}{l}0.049^{\star \star \star} \\
(0.005)\end{array}$ & $\begin{array}{l}0.049^{\star \star \star} \\
(0.005)\end{array}$ & $\begin{array}{l}0.049^{\star \star \star} \\
(0.005)\end{array}$ \\
\hline Cut 1 & $\begin{array}{l}0.700^{\star \star \star} \\
(0.068)\end{array}$ & $\begin{array}{l}0.699 \star \star \star \star \\
(0.068)\end{array}$ & $\begin{array}{l}0.698^{\star \star \star} \\
(0.068)\end{array}$ & $\begin{array}{l}0.699^{\star \star \star} \\
(0.068)\end{array}$ \\
\hline Cut 2 & $\begin{array}{l}1.642^{\star \star \star} \\
(0.068)\end{array}$ & $\begin{array}{l}1.642^{\star \star \star} \\
(0.068)\end{array}$ & $\begin{array}{l}1.641^{\star \star \star} \\
(0.068)\end{array}$ & $\begin{array}{l}1.642^{\star \star \star} \\
(0.068)\end{array}$ \\
\hline Cut 3 & $\begin{array}{l}2.594^{\star \star \star} \\
(0.068)\end{array}$ & $\begin{array}{l}2.593^{\star \star \star} \\
(0.068)\end{array}$ & $\begin{array}{l}2.593^{\star \star \star} \\
(0.068)\end{array}$ & $\begin{array}{l}2.593^{\star \star \star} \\
(0.068)\end{array}$ \\
\hline Cut 4 & $\begin{array}{l}4.050^{\star \star \star} \\
(0.068)\end{array}$ & $\begin{array}{l}4.050^{\star \star \star} \\
(0.068)\end{array}$ & $\begin{array}{l}4.049^{\star \star \star} \\
(0.068)\end{array}$ & $\begin{array}{l}4.049^{\star \star \star} \\
(0.068)\end{array}$ \\
\hline Test $\left(\chi^{2}\right)$ EB_AUS $=$ TB_AUS & & & $14.03^{\star \star \star}$ & 2.36 \\
\hline Observations & 677,702 & 677,702 & 677,702 & 677,702 \\
\hline Pseudo- $R^{2}$ & 0.0352 & 0.0352 & 0.0352 & 0.0352 \\
\hline
\end{tabular}

Notes: All estimations include country/year dummies; sample selection correction. Columns (2) and (4) also include occupation dummies. Clustered SEs in parenthesis. See Table A1 for variable and acronym descriptions.

Significance at the ${ }^{\star} 10 \%, \star \star 5 \%, \star \star \star 1 \%$ level. 